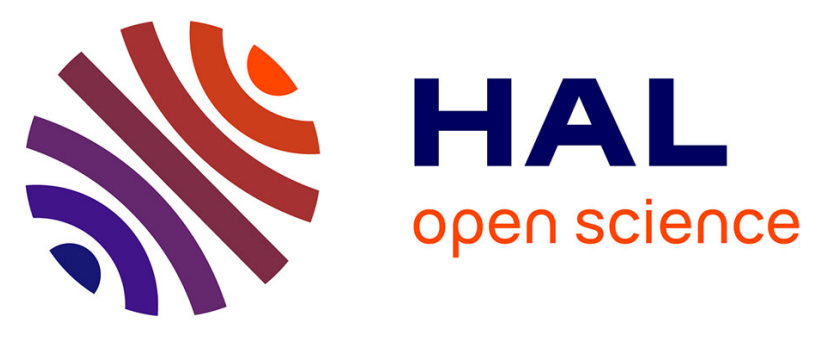

\title{
Interactions between active tectonics and gravitational deformation along the Billecocha fault system (Northern Ecuador): Insights from morphological and paleoseismological investigations
}

Herve Jomard, Diana Saqui, Stephane Baize, Alexandra Alvarado, Benjamin Bernard, Laurence Audin, Silvana Hidalgo, Daniel Pacheco, Mario Ruiz, Monica Segovia

\section{- To cite this version:}

Herve Jomard, Diana Saqui, Stephane Baize, Alexandra Alvarado, Benjamin Bernard, et al.. Interactions between active tectonics and gravitational deformation along the Billecocha fault system (Northern Ecuador): Insights from morphological and paleoseismological investigations. Journal of South American Earth Sciences, 2021, 111, pp.103406. 10.1016/j.jsames.2021.103406 . hal-03360612

\section{HAL Id: hal-03360612 \\ https://hal.science/hal-03360612}

Submitted on 30 Sep 2021

HAL is a multi-disciplinary open access archive for the deposit and dissemination of scientific research documents, whether they are published or not. The documents may come from teaching and research institutions in France or abroad, or from public or private research centers.
L'archive ouverte pluridisciplinaire HAL, est destinée au dépôt et à la diffusion de documents scientifiques de niveau recherche, publiés ou non, émanant des établissements d'enseignement et de recherche français ou étrangers, des laboratoires publics ou privés.

\section{(2)(1) $\$$}

Distributed under a Creative Commons Attribution - NonCommercial - NoDerivatives 44.0 
1 Interactions between active tectonics and gravitational deformation along the Billecocha

2 fault system (Northern Ecuador): insights from morphological and paleoseismological investigations.

4 Jomard H. ${ }^{1}$, Saqui D. ${ }^{2}$, Baize S. ${ }^{1}$, Alvarado A. ${ }^{2}$, Bernard B. ${ }^{2}$, Audin L. ${ }^{3}$, Hidalgo S. ${ }^{2}$, Pacheco

$5 \quad \mathrm{D}^{2,4}$, Ruiz M. ${ }^{2}$ and Segovia M. ${ }^{2}$

${ }^{1}$ Institut de Radioprotection et Sûreté Nucléaire, 92262 Fontenay-aux-Roses, France

${ }^{2}$ Instituto Geofisico, Escuela Politécnica Nacional (IG-EPN), Ap. DI. 01-2759, Quito, Ecuador

${ }^{3}$ Institut des Sciences de la Terre, IRD: UR219, Université Joseph Fourier-Grenoble I-INSU-OSUG, Grenoble, France

${ }^{4}$ Géoazur, CNRS, Université Côte d'Azur, IRD, Observatoire de la Côte d'Azur, Valbonne, France,

Corresponding author: Herve.jomard@irsn.fr

Keywords: Active tectonics, volcano-tectonic interactions, paraglacial deformations, Ecuador, Paleoseismology, deep seated gravitational slope deformations (DSGSD)

\section{Abstract}

The Billecocha plateau (4000 $\mathrm{m}$ a.s.l.) lies in the high elevation Ecuadorian Andes volcanic arc. It overhangs by $2000 \mathrm{~m}$ above the interandean valley. Both the plateau and surrounding volcanoes are heavily affected by active faulting characterized by straight, sharp and discontinuous scarps within a $6 \mathrm{~km}$ wide and $24 \mathrm{~km}$ long corridor. Contrasting interpretations have been proposed to explain the expression at surface of the so-called Billecocha fault system (BFS), from normal faulting related to postglacial elastic rebound or gravitational processes, to rightlateral faulting compatible with the North-Andean Sliver tectonic regime. The instrumental seismicity recorded around the BFS is low, however, a M 7 earthquake heavily struck the region in 1868.

With the aim to discuss the kinematic and coseismic nature of the encountered deformations as well as the seismogenic character of the BFS, we performed (1) morphological analysis to map and quantify evidence of active faulting and (2) paleoseismological investigations across the longer segment of the fault system. In three trenches, we show that surface deformations are at least partly coseismic in origin during the Holocene with a minor lateral component, the last paleoseismic event being compatible in date with the 1868 earthquake. In addition, some of the enlightened paleoseismic events could have occurred in relationship with volcanic eruptions of the surrounding volcanoes.

While field evidence of reverse and strike slip faulting suggests that regional tectonics could be involved, the geomorphological signature of the BFS at the mountain scale, as seen on the digital surface model, can partly be related to the development of deep seated gravitational deformations, hence suggesting an interaction between boundary (i.e. tectonic, volcanic) and body forces (i.e. gravity, post-glacial rebound). Further studies are however 
mandatory to better address the influence of each process at the BFS, in particular geodetic and seismological surveys.

Given the available data, we suggest that the BFS could actually correspond to the distributed surface expression of the tectonic reactivation of the inherited Pujili suture, enhanced by gravitational phenomenon. In this light, paleoearthquakes identified along the BFS may help evidencing the recurrence of major events in the region. However, it also imply that surface deformations along the BFS shall not be used without a careful and more detailed field work to derive fault slip rates for seismic hazard calculations.

\section{1- Introduction}

In the high mountains of Ecuador, a fault system affecting the Billecocha plateau ( $4000 \mathrm{~m}$ a.s.l.) and surroundings presents outstanding landforms related to active faulting. A study published by Ego et al. (1996a), the only one published to date concerning the Billecocha fault system (hereafter mentioned as BFS), concludes that the faults observed at the surface are not related to active tectonics but to lithospheric forces, and most likely due to the unloading of the Billecocha plateau, located at high altitude, after the last deglaciation. Other main conclusions of that study is that the kinematic of deformation along the BFS are purely normal, occurring along bedding planes playing the role of structural discontinuities; and that they happened in between $10000 \mathrm{yr}$. cal BP and 6000 yr. cal BP. In contrast, a more recent study conclude that regional active faults (including the BFS) belongs to a wider dextral strike-slip fault system, in agreement with regional seismotectonic data (Alvarado et al., 2016). Such differences in interpretation remind that the interpretation of active tectonic geomorphology in mountainous area often lead to debates. Hippolyte et al. (2006) for instance reports that active fault scarps in mountains can be created either by coseismic tectonic surface rupture, by post-glacial isostatic rebound or by deep-seated gravitational spreading. In addition, differential erosion processes can often lead to misinterpret active fault scarp-like morphologies (Blackwelder, 1928). In the end, criteria to discriminate the origin of active fault scarp-like landforms in mountainous regions are often difficult to define and to interpret unambiguously (McCalpin, 1999, Ortuño, 2013), which may finally lead to erroneous interpretations that propagate in seismic hazard evaluations.

The uncertainty concerning the origins of the BFS landforms happens in a context where a Mw 7.2 earthquake struck the area in 1868, and where Beauval et al (2010) proposed an epicentral area compatible with its occurrence in the vicinity of Billecocha. This then makes the BFS a possible candidate to being the source of this earthquake. In this paper, we aim at providing new geomorphological and chronological data to refine the available fault mapping, estimate fault cumulative offset and slip history, and finally shed new light on the type of kinematics related to this fault system. In particular we:

- Present a new morphological study based on the analysis of a high resolution digital surface model (DSM) as well as orthophotos acquired at the country scale (data available at www.sigtierras.gob.ec); 
- Evaluate through a paleosesismological survey if the Holocene surface deformations registered along the main fault segment of the BFS are coseismic in origin or not, and discuss the seismogenic character of the fault system;

- Discuss the different processes that could have participated to the development of the mapped landforms and evaluate if the BFS could be the source of the 1868 earthquake.

\section{2- General settings}

The Ecuadorian Andes are located in the northern part of the Andean mountain chain that runs all along the western side of South America. The chain crosses Ecuador from north to south over a distance of about $600 \mathrm{~km}$. Compared to the southern Andes, the chain is here very narrow (150-180 km, Coltorti and Ollier, 2000) and can be divided in two cordilleras (namely the Eastern and Western cordilleras, Figure 1), with mean altitudes around $4000 \mathrm{~m}$ a.s.l. Those cordilleras are separated to the North by a narrow and densely inhabited intramontaneous valley named the interandean valley (IAV) at a mean altitude of $2800 \mathrm{~m}$ a.s.I.

Whereas the geological basement of the Ecuadorian cordilleras results of a complex geodynamical history lasting from the Cretaceous to Early Cenozoic (Lebras et al., 1987; Hughes and Pilatasig, 2002; Jaillard et al., 2009; Pindell and Kennan, 2009), the actual morphology of the chain results from the onset and the evolution, since Miocene times (Steinman et al, 1999; Deniaud, 2000; Hungerbühler et al., 2002), of the subduction of the Nazca plate and the Carnegie ridge below the South American plate (Gutscher et al., 1999; Spikings et al., 2001). The uplift of the chain jointly occurred with the built of a volcanic arc that contributed to the edification of the actual known reliefs, where active volcanic edifices can nowadays reach altitudes higher than $6000 \mathrm{~m}$ and where thick volcanosedimentary sequences actually model the Ecuadorian Andes landscapes (Hall and Beate, 1991; Hall et al., 2008, Bablon et al., 2019)

The current seismotectonic activity in continental Ecuador is dominated by the subduction of the Nazca plate beneath the South American plate at a convergence rate estimated at 6-7 cm per year (White et al., 2003, Nocquet et al., 2014). While the deformation of coastal areas is dominated by the interseismic coupling of the subduction interface, deformation of more internal areas in the Ecuadorian Andes also results from the oblique component of the convergence (Nocquet et al., 2014, Yepes et al., 2016). It produces a consecutive motion of the "North Andean Block" (Kellogg and Vega, 1995; Alvarado et al., 2014) toward the north-east with respect to the South American plate at a rate of $\sim 8 \mathrm{~mm}$ per year (Nocquet et al., 2014). This block was later defined as the "North Andean Sliver" by Nocquet et al. (2014) in order to depict the observed geodetic deformations, mainly distributed around the dextral strike-slip Chingual-Cosanga-Pallatanga-Puná (CCPP) fault system (Alvarado et al., 2016) that runs all along Ecuador until the Caribbean Sea through Colombia and Venezuela. The CCPP initiates within the gulf of Guayaquil and runs across both eastern and western cordilleras as well as the IAV (Figure 1), cutting obliquely the accreted terranes and sub-meridian structures of the Ecuadorian Andes (Alvarado et al., 2016, Baize et al., 2020a). 
Large scale neotectonic studies in Ecuador started in the 1980's for risk preparedness purposes, focusing on the northern part of the Ecuadorian Andes (Soulas et al., 1987; Soulas, 1988), and extended to the overall chain by Ego (1995) in order to discuss the state of stress in the country (Ego et al., 1996b).The first detailed map and database of active faults was compiled and published by Egüez et al. (2003) in the framework of an international program, later detailed and improved by Alvarado (2012). Apart from these national/regional scale studies, more specific studies in terms of active tectonics mainly concentrated along the CCPP fault system, thought to be the source of some of the biggest destructive earthquakes that shook Ecuador since the $16^{\text {th }}$ century such as the 1797 Riobamba earthquake (Winter et al, 1993; Baize et al., 2015, 2020a, Figure 1), which is, with an estimated magnitude of $\mathrm{Mw}^{\sim} 7,6$ (Beauval et al., 2010), the biggest crustal earthquake known in South-America. The CCPP was for instance studied along the fault segments of Pallatanga (Winter et al, 1993; Baize et al., 2014, 2020), Cosanga (Champenois et al., 2017) and Chingual (Tibaldi et al., 2007). However, other reported crustal earthquakes with estimated magnitudes around 7 occurred in the Ecuadorian Andes away from the CCPP fault system (Beauval et al., 2010), but few scientific publications concentrated along other fault systems of the Ecuadorian Andes. These studies concerns the Latacunga faults and folds (Dávila, 1990; Lavenu et al., 1995; Fiorini and Tibaldi, 2012; Baize et al., 2020), the Quito reverse fault system (Alvarado et al., 2014; Marinière et al., 2020), the fold and thrusts affecting the frontal part of Eastern Cordillera at the Rio Pastaza alluvial fan (Bès de Berc et al., 2005) and the Billecocha fault system (Ego et al., 1996a). The latter is the only published study in the region where the Ibarra 1868 earthquake have occurred the $16^{\text {th }}$ of August ( $M w^{\sim} 7,2$; Beauval et al., 2010). However, the studied fault where concluded to a non-tectonic origin (i.e. geodynamic process different from block tectonics). 


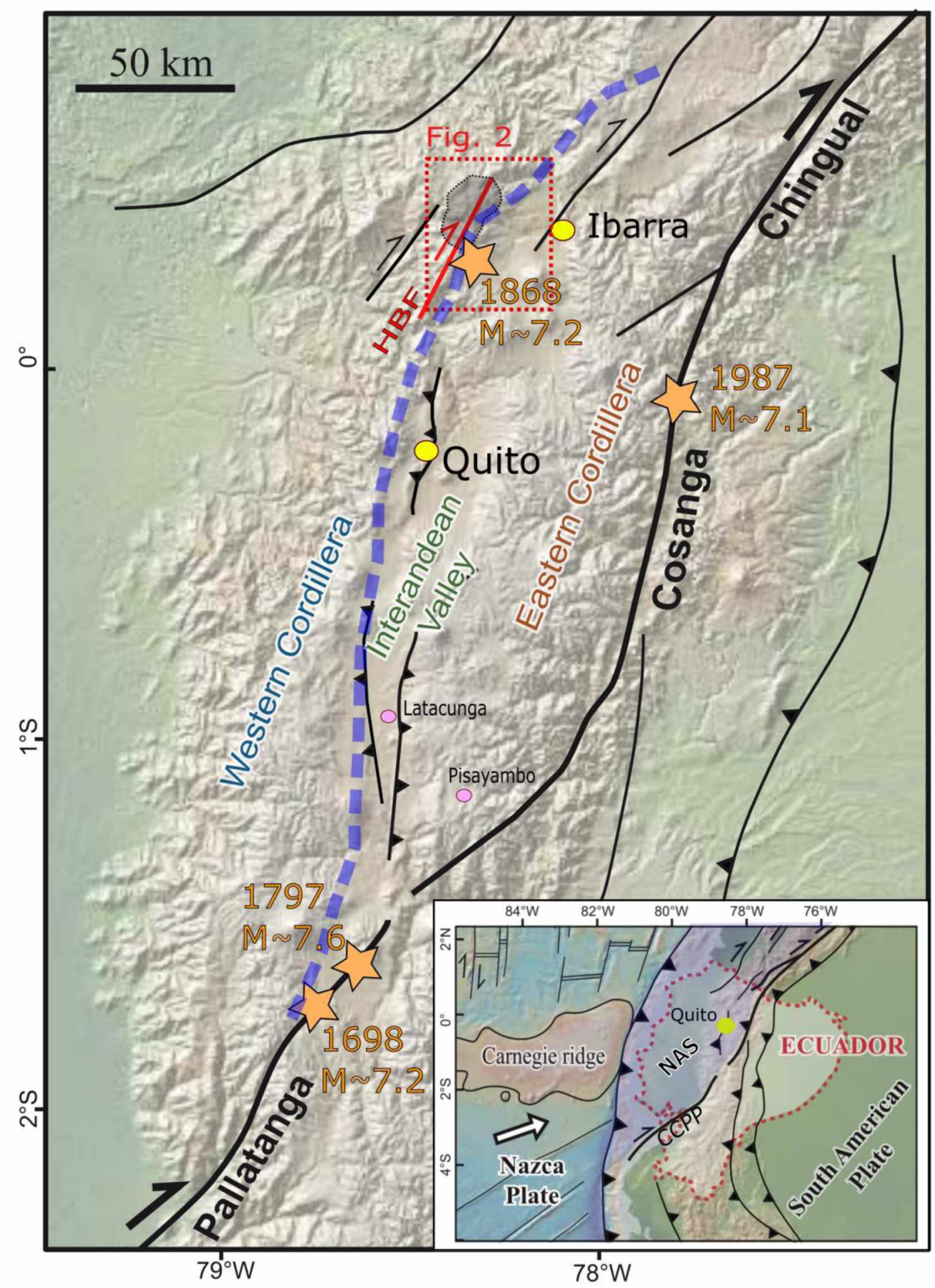

Figure 1 : OVerVIEW of the geodynamical context of ECuAdor (MODIFIEd from Bablon et AL., 2019). IN THE LOWER RIGHT CORNER, THE WHITE ARROW INDICATES THE DIRECTION OF PLATE MOTION RELATIVE TO SOUTH AMERICA AND

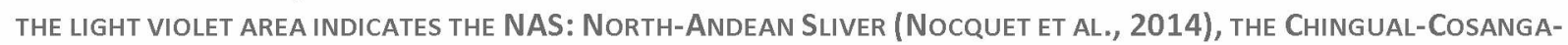
Pallatanga-Puna fault is referred as CCPP (Alvarado et AL., 2016). Main ACtive faults ARe RePresented by


line (After Alvarado et Al., 2016 and Baize et AL., 2020). Orange stars are the location, dates and MAGNITUDES OF MAJOR CRUSTAL EARTHQUAKES (M>7, BEAUVAL ET AL., 2013). THE DARKER AREA REPORTED IN THE FRAME OF FIGURE 2 REPRESENTS THE SPATIAL IMPRINT OF THE BILLECOCHA AREA. PINK DOTS CORRESPOND TO SPECIFIC AREAS MENTIONED IN THE TEXT. 


\section{a) General settings}

The Billecocha region as described in the following sections belongs to the northern part of the Western Cordillera, located west of the cities of Otavalo and Cotacachi (Figure 2). It encompasses the so-called Billecocha plateau at a mean altitude of $4000 \mathrm{~m}$ a.s.l.; the Pleistocene to Holocene Cotacachi-Cuicocha volcanic complex (4937 $\mathrm{m}$ a.s.l.) located south of the plateau and the composite Chachimbiro volcano (4076 m a.s.l.) located north; and finally the slope running from the plateau toward the IAV, corresponding to the eastern edge of the Western cordillera.

The basement of the Western Cordillera consists in highly contorted and often vertical (Coltorti and Ollier, 1999) terranes, dipping roughly $75^{\circ}$ to the East in the Billecoccha area (Egüez, 1986; Ego et al., 1996a). It is composed with (1) mafic crustal formations accreted to a continental margin by the late Cretaceous (Pallatanga terranes, Hughes and Pilatasig, 2002; Vallejo et al., 2009) and reported locally as Naranjal and Rio Cala formations (Boland et al., 1998); and with (2) overlapped Eocene to Miocene magmatic arcs and associated sediments (Macuchi terranes, Hughes and Pilatasig, 2002; Vallejo et al., 2009), reported locally as Silante formation (Boland et al., 1998). On top of this basement, Quaternary andesitic deposits related to the activity of the surrounding volcanoes compose the major part of Billecocha's outcrops (Boland et al., 1998). These are ultimately covered by late Pleistocene/Holocene glacial and post glacial deposits, on which marshes and Andean páramo develops along with volcanic ejecta (Colmet-Daage et al., 1967; Zehetner et al., 2003). Very little is known concerning the last ice age and related deposits in Billecocha. Based on the available literature in Ecuador (e.g. Clapperton and Vera, 1986) and on geomorphological arguments, Ego et al., (1996a) reported the presence of a 120m thick icefield covering the plateau at the maximum extent of the glaciers between 21000 and $12000 \mathrm{yr}$. BP.

The eastern edge of the western Cordillera is highly deformed along the Pujili fault zone (Hughes and Pilatasig, 2002; i.e Pujilí-Calacalí - Pallatanga-Calacalí-Pujilí - Pujilí suture zone depending on the authors, Figure 1) acting as a major tectonic boundary since the Cretaceous (Litherland and Aspden, 1992). Some segments of this large scale structure have been characterized as active during the Quaternary (Egüez et al. 2003) and capable of producing earthquakes (Alvarado, 2012). Among them, the Billecocha fault system (hereafter BFS, Ego et al., 1996a; Egüez et al., 2003; Saqui, 2019) was characterized as a section of the Billecocha - Huayrapungo fault (Figure 1), belonging to a larger system of dextral faults of unknown slip rates, probably less than $1 \mathrm{~mm} / \mathrm{yr}$ (Egüez et al., 2003). Whereas the Huyarapungo fault section located further south in continuation of the BFS highlights morphological and microtectonic evidence of active strike-slip faulting (Egüez et al., 2003), the morphological signature of the BFS led Ego et al., (1996a) to propose a normal kinematics for this fault system and, together with an abnormal throw-to-length ratio, an origin due to local processes different from far-field tectonics. Such a non-tectonic origin of the BFS have the advantage to clarify the occurrence of apparent normal faulting within the actual stress regime affecting the wider area of the El Angel seismoctectonic zone (Yepes et al., 2016), highlighting right-lateral strike-slip motion and E-W shortening from earthquake focal mechanisms (Vaca et al., 2019). This stress regime is also coherent with active fault systems mapped within the IAV, showing both reverse 

of the area however preclude any estimation of GPS-derived local strain tensor. Concerning volcanoes surrounding the Billecocha plateau, the activity of the Cotacachi-Cuicocha volcanic complex is mainly known to be Pleistocene for Cotacachi (173 to 65ka, Almeida et al., 2019), followed by a much more recent eruptive phase at Cuicocha, starting 5000 yr. BP and culminating during a VEI5 eruption (2990 yr. BP, Mothes and Hall, 1991), finally followed by the extrusion of intra caldera domes. Similarly, the main volcanic activity at Chachimbiro is thought to be Pleistocene, but more regular activity was also reported during the Holocene, with 4 to 6 eruptions within the last six thousand years, the last of them occurring circa 2000 yr. BP (Bernard et al., 2011). 




Seismicity Catalogue (Beauval et al., 2013, Ypiales, 2019; Instituto Geofisico 2020)

$$
\cdot M<2 \text { ○M 2-3 OM 3-4 OM 4-5 OM 5-6 OM 6-7 } \bigcirc \text { M 7-8 }
$$

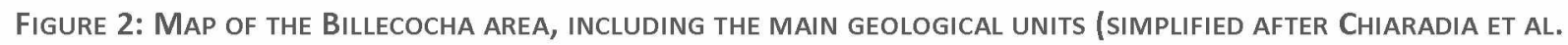
2011 and Bellver-Baca et Al., 2020), Pleistocene and Holocene volcanoes (After Bernard et Al., 2011; Beguelin et Al., 2015; Almeida, 2016; Andrade et Al., 2019; Bablon et Al., 2020; Sierra et AL., 2020;

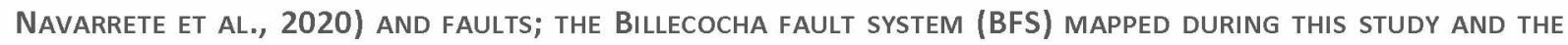
AVAILABLE SEISMICITY CATALOGUES.




al., 2010) and 1955 (Mw 6; Beauval et al., 2010, Ypiales, 2019) within the Imbabura Province (Figure 2). Apart from these, the area has a relatively low seismicity in comparison of other active regions in Ecuador.

We compiled available seismologic data from (1) the seismic catalogue of Beauval et al., (2013), designed for seismic hazard assessments and merging together both the instrumental and historical seismicity from 1589 to 2009 (3.1<Mw<8.8); (2) an extraction of the instrumental catalogue of the Instituto Geofísico for the El Angel seismotectonic zone from 2011 to $2020(0<\mathrm{Mw}<4.3)$; and (3) more specific studies concerning the 1955 earthquake (Ypiales, 2019) or using temporary seismological networks nearby Cotacachi (García-Villarruel, 2018) and Chachimbiro volcanoes (Cordova Regalado, 2013), both set up for few months. From this compilation, one can observe (Figure 2):

- The seismicity occurring in the vicinity of the BFS appears very low and diffuse. During the 2011 to 2020 period, the level of seismic detectability for the Billecocha area is close to $M=2$, which could be a reason for the absence of microseismicity in the area. This could for example be illustrated by the study of Córdova-Regalado (2013) where a temporary network was installed around the Chachimbiro volcano. During the 4 months of monitoring, 900 events low magnitude events were recorded around Chachimbiro, with few poorly constrained transcurrent focal mechanisms;

- The seismicity recorded near the Cuicocha and Cotacachi volcanoes is denser and clustered. The cluster located just north of Cotacachi was relocated by García-Villarruel (2018) resulting in a shallow (mainly between 1 and $2 \mathrm{~km}$ depths) earthquake swarm with long period earthquakes associated with hydrothermal activity and some deeper transcurrent focal mechanisms interpreted as mostly volcanotectonic in origin. Earthquakes located around the Cuicocha lake may also be of volcano-tectonic origin, considering the late Holocene activity of this volcano (Günkel et al., 2009);

- Rare earthquakes with magnitudes between 3 and 5 and coming from the Beauval et al. (2013) seismic catalogue has struck the area since the onset of instrumental networks. However, the uncertainty concerning both their location and depths does not allow detailed discussion of possible sources of these events (as highlighted in Champenois et al., 2017).

Concerning the historical events that occurred in the Imbabura province, the most important one occurred the $16^{\text {th }}$ of August 1868, early in the morning (Aguilar, 1868). It is by far the biggest event reported in the region. The earthquake, known as the Ibarra earthquake, occurred a day after another earthquake of estimated magnitude 6.6 for which the epicenter is estimated further 40 to $50 \mathrm{~km}$ to the North (Beauval et al., 2010). If the latter is poorly known, the Ibarra earthquakes is known from many testimonies. Maximum reported intensities reached the level of IX in the MSK-64 macroseismic scale (Singaucho, 2009). The earthquake also caused widespread environmental effects, in particular landsliding, causing a significant number of the reported casualties (Egred, 2009). After a careful revision of the available documents, Singaucho (2009) proposed that the cities of Otavalo and Cotacachi were the most impacted, leading Beauval et al. (2013) to locate there the epicentral area. However, it is clear that the location of the epicenter is mainly driven by the distribution of settlements in the IAV, which may bias the real location of the earthquake. Taking this uncertainty into account, Beauval et al. (2010) proposed an exploration of the possible epicentral location of the event, which could be compatible with 
an occurrence nearby or at the BFS. Owing to the widespread distribution of damage as well as the uncertainty related to its epicentral location in the Imbabura province, this earthquake should be more properly called Imbabura Earthquake.

The second major historical event occurred the $20^{\text {th }}$ of July 1955 (Cotacachi earthquake), with an estimated magnitude of 6 (Beauval et al., 2013, Ypiales, 2019). The maximum intensities reported are VIII in both MSK64 and EMS98 macroseismic scales (Beauval et al 2010, Ypiales, 2019 respectively). Because the macroseismic field is restricted in size, Ypialies was able to relocate the epicenter with a relatively good confidence south of Cotacachi city. He also proposed a probable seismogenic source for this event within the IAV.

The epicentral location of both 1868 and 1955 events are very close to each other (Figure 2). However, the epicentral location of the 1868 earthquake is by far more uncertain (tens of kilometers) than the other (few kilometers, see Beauval et al., 2010 for further details), which means that it is not possible to attribute these events to a single seismogenic structure. Because we can expect that those large magnitude events could be morphogenic with surface ruptures, we investigate the BFS and especially their geometry (length, segmentation) and their recent slip timing whether they could be the source of those major events.

\section{4- Collected data}

\section{a) Geomorphic signature of the BFS}

In this section, we take advantage of the 4 meters spatial resolution DSM available at the national scale (http://www.sigtierras.gob.ec/) as well as field observations collected in 2018. All measurements presented hereafter derive from the use of this DSM, considered as a reliable proxy of the natural relief. This hypothesis is supported by the fact that (1) the Billecocha area was not or little modified by human activities during the history, and (2) the vegetation is short and relatively homogeneously distributed.

The BFS was first mapped by Ego et al. (1996a), where the authors were able to recognize 5 fault segments after air photo and field analysis. They mapped those segments over an $11 \mathrm{~km}$ long and $2 \mathrm{~km}$ wide zone. Later on, Alvarado (2012) and Saqui (2019) proposed new mappings based on updated datasets. In this study, we propose a renewed analysis of the $4 \mathrm{~m}$ DSM already analyzed by Saqui (2019), increased with orthophotos and field observations (Figure 3). The main criteria used to perform this mapping are (1) faults displace quaternary deposits (mainly Pleistocene to Holocene) (2) faults affects quaternary morphologies (post glacial morphologies, active drainages and slopes). 



Figure 3: Frame a is a MAP of the BFS as derived from the ANAlysis of the DSM, Where frames 3B to 3e are LOCATED AS WELL AS THE LOCATION OF THE TRENCH SITE (FIGURE 6) AND THE SLOPE PROFILE OF FIGURE 4 (DOTTED LINE BETWEEN $X$ AND $Y$ ). FRAMES B AND C FOCUS ON THE MAIN BILleCOCHA FAULt STRANDS, AFFECTING FRONTAL MORAINES and a Pleistocene lava flow (Frame B). The main drainage System is Presented as blue dotted lines and ponds


QUANTIFY LATERAL FAULT DISPLACEMENTS (FRAME C). A PICTURE OF THE MAIN FAULT STRAND IS INCLUDED IN FRAME C. FRAME D IS A PICTURE OF A COUNTERSCARP OBSERVED WITHIN THE SLOPE TOWARD THE INTER-ANDEAN VALLEY. FRAME E: FOCUS ON A LOCALIZED DEEP SEATED GRAVITATIONAL SLOP DEFORMATION WHERE COUNTERSCARPS AFFECT A NE ORIENTED SLOPE. THE BASEMAP OF FRAMES A, B, C AND E ARE HILLSHADES DERIVED FROM THE 4M RESOLUTION DSM OF ECUADOR (WWW.SIGTIERRAS.GOB.EC). 
These high resolution data allow us to map a series of 140 lineaments, occurring in a $24 \mathrm{~km}$ long and $6 \mathrm{~km}$ wide zone, much larger than the one observed in the 1990's. The longest fault segment, reported earlier by Ego et al., (1996a) now reaches $12 \mathrm{~km}$ long instead of 10. Faults are mainly linear, cutting sharply the crossed morphologies and deposits. This new mapping, contrarily to that of Ego et al. (1996a), shows an arcuate general shape, which is noticeable at the mountain-range scale, running from $\mathrm{N}^{\circ} 0^{\circ} \mathrm{E}$ to the south and along the two third of the $\mathrm{BFS}$, and turning $\mathrm{N}^{\circ} 0^{\circ} \mathrm{E}$ in its northern part. In general, faults are better expressed within the plateau and near the crests, more discontinuous in steep slopes, especially those toward the IAV where linear incision is higher.

The BFS affects different morphologies and geological units of contrasting ages, crossing from south to north (Figure 2):

- Deposits related to the recent Cuicocha VEI5 eruption (2990 yr. B.P., Mothes and Hall, 1991) and deposited along the southern flank of the Cotacachi volcano;

- The Pleistocene Cotacachi volcanic edifice (Almeida, 2016; Bablon et al., 2020). The BFS deforms the summit as well as the northern slopes of the edifice, along which lava flows of unknown ages as well as different stages of morainic cordons and fronts could be observed (Ego et al., 1996a) and are offset (Figure 3a);

- The Billecocha plateau and its eastern slopes toward the IAV (Figure 4). The BFS affects basement lithologies and morphologies shaped by glaciers and linear erosion, moraines and Holocene deposits covered by andisols and marshes (see description in the paleoseismological section);

- The Pleistocene to Holocene compound Chachimbiro volcanic complex (Bernard et al., 2011; BellverBaca et al., 2020) until its northern slopes.

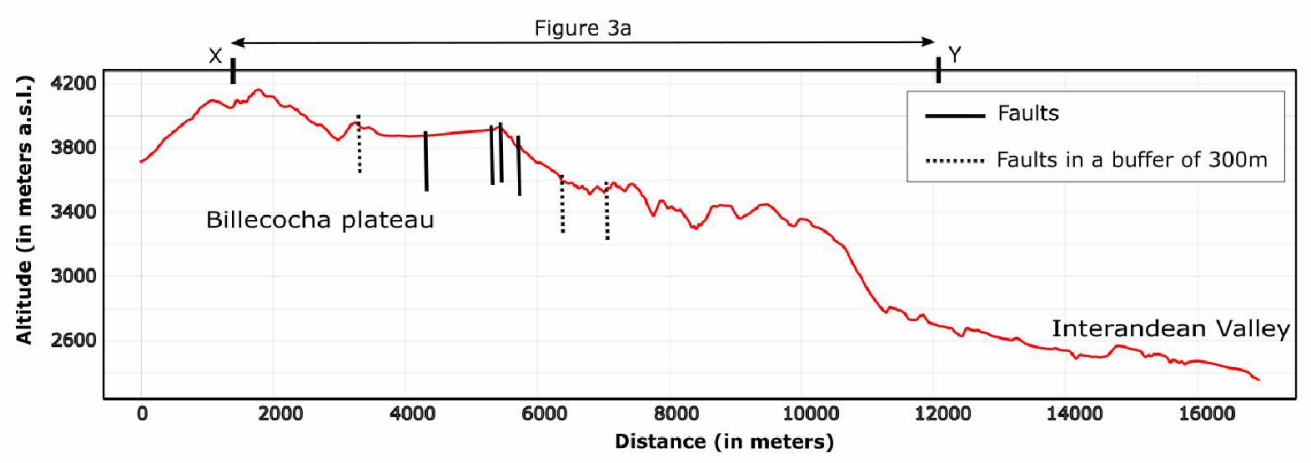

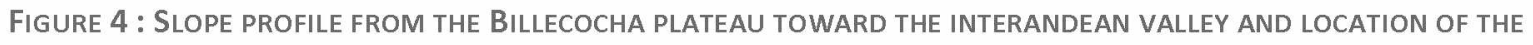
MAPPED FAULTS. THE IMPRINT OF THE SLOPE PROFILE ON FIGURE 3A IS REPORTED IN BETWEEN X AND Y.

As mentioned before, the morphology of the area was modeled by glaciers. Indeed, remnants of morainic fronts are present at altitudes as low as $\mathbf{3 2 0 0} \mathbf{m}$ north of Chachimbiro, which is coherent with the presence of an ice cap in the area during the last glacial maximum, somewhere between $35000 \mathrm{yr}$. BP and $10000 \mathrm{yr}$. BP (Clapperton and Vera, 1986; Ego et al., 1996a). Different stages of glacier retreat are inferred from the occurrence of morainic fronts lying at different elevations until the flanks of the Cotacachi volcano (Figure 3a). Moraine remains such as those observed above $4000 \mathrm{~m}$ could be relatively recent, considering that a glacier was present on this volcano until the beginning of the $X X^{\text {th }}$ century (Rhoades, 2008). Based on this statement and the total absence of datings 
on these deposits, we discuss the further results of fault displacements and rates based on the speculative hypothesis that they mainly postdate the last glacial period (post $12000 \mathrm{yr}$. BP).

In figures $3 \mathrm{~b}$ to $3 \mathrm{e}$, we report observations that depict a representative sample of the scarps and landscape features of faults related to the BFS. The main expression of the BFS at the surface, as reported by Ego et al., (1996a), coincide with the occurrence of linear and steep fault scarps. A majority of these scarps are east facing, especially within the plateau, with an apparent uplifted western block with respect to an eastern one. West facing scarps are also noticeable, especially affecting the slopes toward the IAV, then reported as counterscarps (Figure 3d). Counterscarps also appear more densely in certain slopes (Figure 3e), along with well individualized deep seated gravitational slope deformations (DSGSD, see for instance Agliardi et al., 2001; Jomard et al., 2014, Jarman, 2006; Jarman et al., 2014 for European examples) that may locally strongly enhance the deformations observed along the BFS (Figure 5). In addition, the BFS has a strong influence on the drainage system and related morphologies and deposits. This is especially the case along the Billecocha plateau where the slope gently dips toward the west and where fault scarps are, on the contrary, facing to the east. Such a configuration allows development of a series of ponds and river captures (Figures $3 b$ and $3 c$ ), which are relevant markers in order to assess the long term kinematic of the faults.

Whereas Ego et al., (1996a) inferred a pure normal faulting kinematics of the BFS, Saqui (2019) proposed a significant right lateral strike slip component based on few observations of river deflections and lateral displacements of moraines observed along some fault segments. A careful analysis of the available datasets all along the mapped BFS allows us to moderate this conclusion:

- Fluvial incision courses highlight evidence of either possible right or left lateral deflections, so that they couldn't be considered here as a relevant marker of long term deformation. This may especially be explained because river deflections are here very sensitive to lithology and local slopes;

- Frontal moraines presented in figure 3b shows, according to Saqui (2019), a right lateral movement of about a meter. This is however also compatible with uplift of the northwestern side of these young moraines relative to their southeastern side. This point is clearly confirmed looking at an older lava flow (older than glacial deposits and probably late Pleistocene in age, Figure 3b), which registered longer term vertical deformations, and showing opposite apparent lateral deflections;

- The shape of ponds that developed along the BFS is often symmetrical around their outlet (Figure 3b and $3 c$ ). There is no detectable and systematic lateral migration of the outlets;

- Longer term morphologies such as crest lines (Figure 3c) does not provide evidence of any cumulative lateral deformations.

Hence, we conclude that the geomorphic expression of active deformations along the BFS is predominantly dipslip, with no significant cumulative horizontal movements, at least detectable with the $4 \mathrm{~m}$ resolution DSM.

Cumulative vertical deformation registered across the complete width of BFS are presented in Figure 5. This plot was performed by summing up the individual measurements of offsets at each segment, along a series of parallel 
profiles. The number of profiles has been locally densified in order to capture deformation on most fault segments. Individual surface offsets were extracted from slope profiles (Bucknam and Anderson, 1979, see supplementary materials for details on the method). Vertical surface offsets along single fault segments range from $0.6 \pm 0.2$ meters to $12 \pm 5$ meters. The total cumulative amount of vertical deformation registered along the BFS, considering that east and west facing structures are independent, reaches $34 \pm 6$ meters, locally increased up to $38 \pm 6$ meters where individualized DSGSD develops (Figure 5). Looking at the overall BFS, and without taking into account the point affected by DSGSD, the deformation profile is rather classical for a single fault system, where cumulative deformations are decreasing toward the fault tips (McCalpin, 2009).



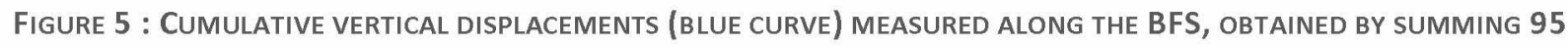
INDIVIDUAL MEASUREMENTS DETERMINED AT EACH INTERSECTION BETWEEN A SERIES OF PARALLEL PROFILES (BLACK DOTTED LINES) AND SEGMENTS OF THE BFS (RED LINES). A CLEAR OUTLIER IN THE DEFORMATION PROFILE CORRESPONDS TO THE LOCALIZED DSGSD REPORTED IN Figure 3E. THE MEAN ALTITUde OF THE MEASUREMENTS IS REPRESENTED WITH THE ORANGE CURVE. THE DISTANCE BETWEEN EACH PROFILE IS 1500M AND 750M WHEN DENSIFIED. YELLOW DOTS ON THE MAP CORRESPONDS TO THE THREE INTERPRETED SLOPE PROFILES REPORTED IN SUPPLEMENTARY MATERIALS.

\section{b) Paleoseismological investigations}

We performed paleoseismological investigations along the longer continuous fault segment of the BFS (Figure 3a) with the aim to maximize our chances to evidence paleoearthquakes and therefore to discuss both the kinematic and the seismogenic character of the fault system. The site was chosen given its relative accessibility (dirt-track), because it presents one of the higher vertical throws observed along the BFS, and because a pond develops at its foot, allowing to preserve deformed sediments. In their study, Ego et al. (1996a) found evidence of a single event along the BFS, post-dating the last glaciation with a minimum age of $5690 \pm 50 \mathrm{yr}$. BP, and 
derived from a sample collected in a road cut. In this study, three trenches were dug across the main fault scarp, where the pond has developed (Figure 6).

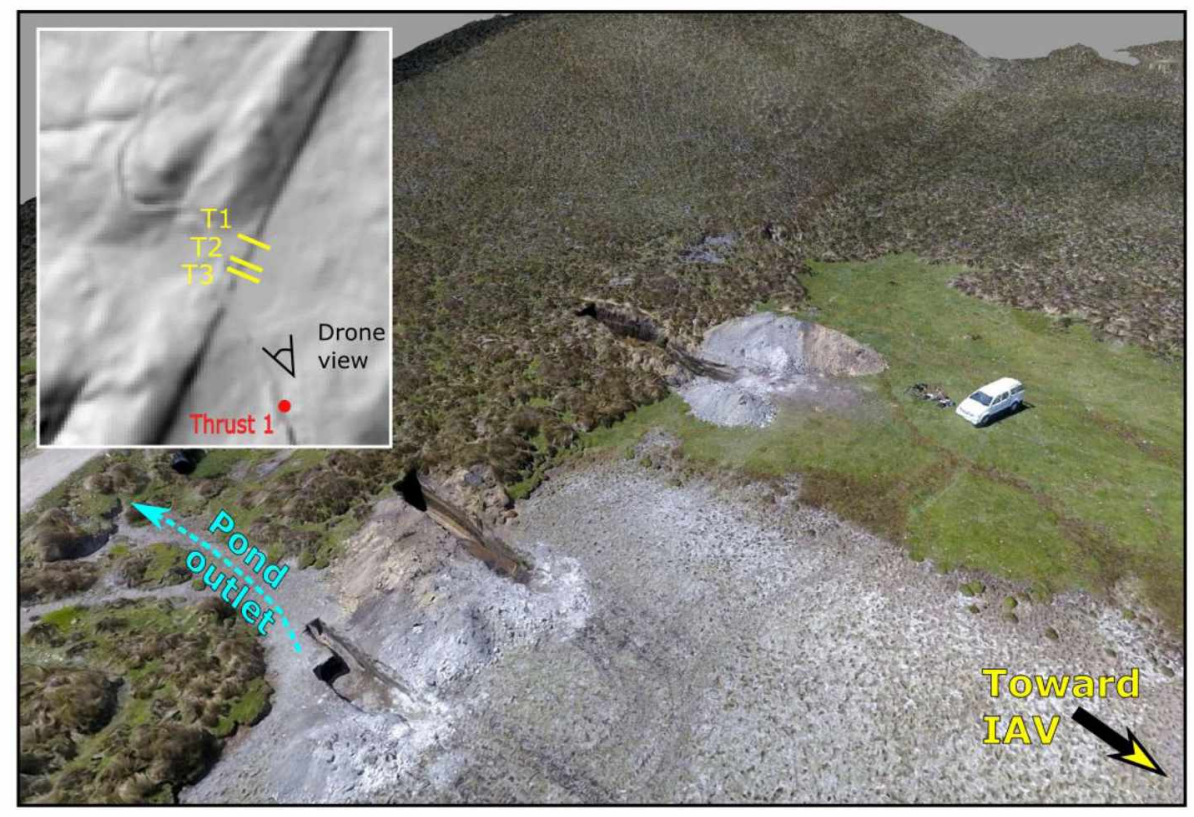

Figure 6 : TOP LEFT: LOCATION OF THE TRENCH T1, T2 AND T3 ON THE DSM HILLSHADE, AS WELL AS THE LOCATION OF THE ROAD CUT EXPOSURE (RF1, FIGURE 9). AND 3D DRAPED MODEL OF THE TRENCH SITE OBTAINED FROM DRONE SURVEY. THE TRENCH SITE LOCATION (WGS 84 COORDINATES: $0.4301^{\circ} \mathrm{N} ;-78,3448^{\circ} \mathrm{E}$ ) IS REPORTED ON FIGURE $3 \mathrm{~A}$.

Trench 1 (Figure 7) is the biggest trench dug, reaching 13 meters long and 3 meters deep, until the water table. Trench 2 and 3 (Figure 8 ) are shorter ( 8.5 and 6 meters long respectively) and shallower ( 2 and 1 meters depth respectively). Trench 1 is the farthest from the pond outlet, where the scarp is higher and where the longest potential seismic record is expected. Trenches 2 and 3 are closer to the pond outlet, where the sedimentation is the most recent and where the most recent events may be captured in the sedimentological record. In the following, we present the southern wall of trench 1 and the northern walls of trench 2 and 3 , the latter being vertically mirrored in order to show coherent trench sections. 


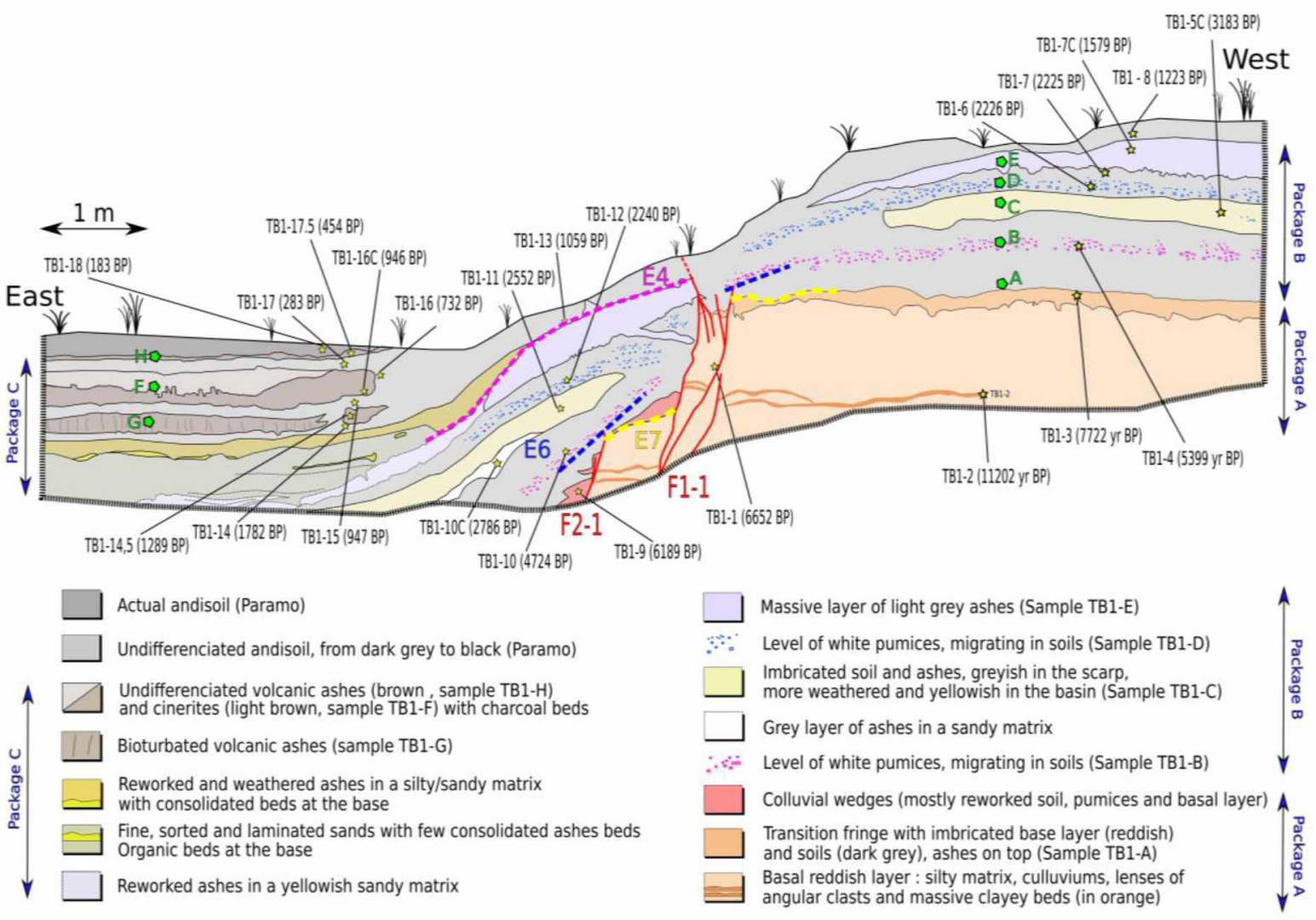

FIgURE 7: INTERPRETED SECTION OF TRENCH 1 WITH A SIMPLIFIED DESCRIPTION OF THE DIFFERENT GEOLOGICAL UNITS. SAMPLES IN VOLCANIC UNITS ARE REPORTED AS TB1-A to TB1-H IN THE LEGEND, AND A to H IN THE FIGURE. SAMPLES FOR C14 DATINGS (TB1-1 TO TB1-18) ARE THE YELLOW STARS; MEAN CALIBRATED AGES ARE ALSO REPORTED ON THE

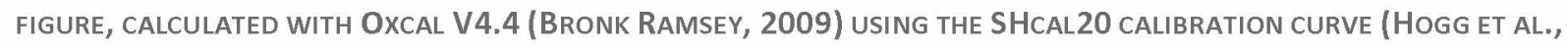
2020). SEDIMENTARY PACKAGES AS DESCRIBED IN THE TEXT ARE REPORTED BOtH LEFT AND RIGHT OF THE CROSS SECTION. FAULT STRANDS ARE REPORTED IN RED AND EVENT HORIZONS ARE REPORTED WITH COLORED DOTTED LINES ASSOCIATED WITH AN E $(x)$ ( $x$ BEING THE NUMBER OF THE EVENT FROM THE YOUNGER 1 TO THE OLDER 7 ). 

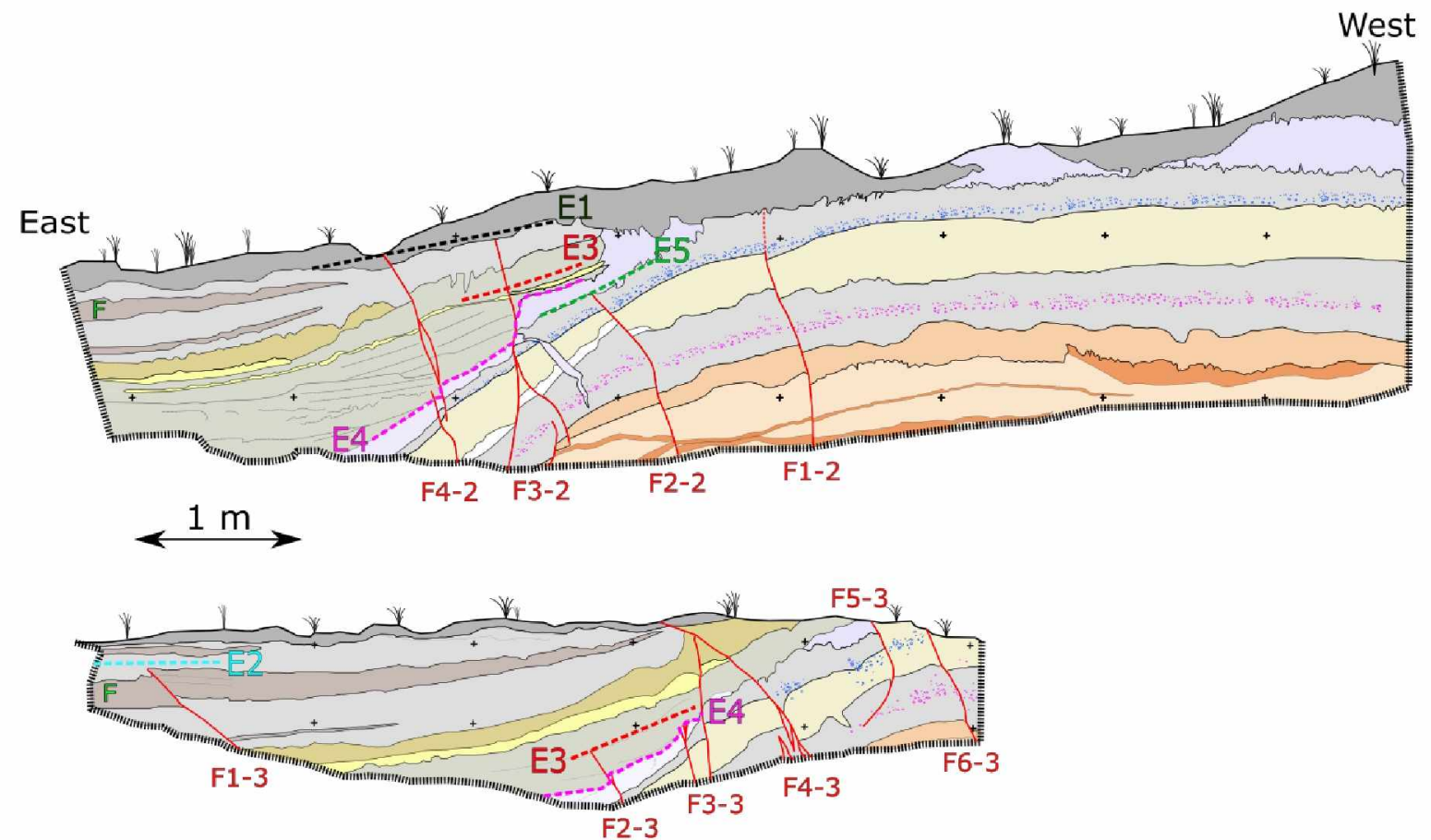

Figure 8 : InTERPRETEd SECTION OF TRENCH 2 (TOP) AND TRENCH 3 (BOTTOM) WITH A COMIMON SCALE. FAULt STRANDS ARE REPORTED IN RED AND EVENT HORIZONS ARE REPORTED WITH COLORED DOTTED LINES ASSOCIATED WITH AN E( $x$ ) ( $x$ BEING THE NUMBER OF THE EVENT FROM THE YOUNGER 1 TO THE OLDER 7).

Chrono stratigraphic description

In the following, we describe the different sedimentary units, from the oldest to the younger ones. In order to make the description easier to follow, those units are divided into three distinct packages from $\mathrm{A}$ to $\mathrm{C}$ (Figure 7). Samples were collected in some of these units for mineralogical analysis (samples TB1 - A to H) and for C14 dating (samples TB1 - 1 to 18). All samples were collected in trench 1 (Figure 7), where the sedimentary record is the most complete.

Ages are provided BP (before yr. 1950) for an easier comparison with previous studies in the area and calibrated with Oxcal software V4.4 (Bronk Ramsey, 2009), using the SHcal20 calibration curve (Hogg et al., 2020), following recommendations after Marsh et al. (2018) concerning the use of calibration curves in South America. Detailed data related to $\mathrm{C} 14$ dating, calibration and associated uncertainties are presented in a table within the supplementary materials. Dates are hereafter presented using the mean value of the $95,4 \%$ confidence level calculated with Oxcal (in yr. cal BP).

\section{Package « $A$ »}

The oldest surface deposits found in the trenches are colluvial to alluvial sediments. They constitute the sedimentary package "A" (Figure 7). With a total thickness of $150 \mathrm{~cm}$, these poorly sorted and massive reddish deposits, consist of clasts packed in an abundant reddish matrix, with a few rare lenses of angular clasts or red clays. The facies evoke a continental environment, with colluvial influence or locally with runoff and weakly channelized pattern. Such deposits suggest a rigorous climate. The $14 \mathrm{C}$ age obtained at the base of the trench places this deposit at the beginning of the Holocene (TB1-2: $11202 \mathrm{yr}$. cal BP). The age derived from a charcoal 
(TB1-1 : 6652 yr. cal BP) is much younger and rather inconsistent with the observed stratigraphy so that we consider it may have been dragged down into the fault zone next to which it was collected, which is coherent with the age of the oldest identified colluvial wedge (see next section, TB1-9: $6189 \mathrm{yr}$. cal BP).

\section{$\underline{\text { Package "B" }}$}

The alluvial complex (Package $A$ ) is overlain by a thick series of volcanic tephra and soils of almost 2 meters thick, with massive ashes encompassing two main levels of pumices (in pink and in blue, Figure 7). These levels appear to be in place in the NW block at the footwall of the fault. They are heavily pedogenized.

At the base, an andesitic ash (sample TB1-A), pedogenized and oxidized, forms a transition with the underlying alluvium/colluvium. This volcanic level has a relatively high $\mathrm{K}$ content (SiO2 59\%, K2O 1.29\%) which marks a volcanic source in the Western Cordillera, probably the nearby Chachimbiro volcano which have comparable values (Bernard et al., 2011 and 2014). The age of the corresponding soil sample (bulk - TB1-3) is $7722 \mathrm{yr}$. cal BP. The fragments of pumice (sample TB1-B) that line the middle part of the oldest paleosoil in Trench 1 correspond to fallout associated with the pyroclastic blast of Chachimbiro satellite dome well known around this volcano (Bernard et al., 2014). The age of the soil samples collected within this level (bulk - TB1-4: $5399 \mathrm{yr}$. cal BP) and on top of it (bulk - TB1-10: $4724 \mathrm{yr}$. cal BP) are consistent with that of the pyroclastic flow recognized by Bernard et al. (2014). The facies of the pumice as well as the chemical composition of rhyodacite (SiO2 67.7\%, K2O 1.57\%), the only one known in the region, confirms this correlation with the so-called "3640-3510 BCE" (i.e. 5590 - 5460 yr. cal BP) eruption (Bernard et al., 2014). This is the oldest layer represented on either side of the fault zone.

Above, a level of greyish ashes and its lapilli's delivered sample TB1-C (SiO2 60.5\%, K2O 1.07\%), on top of which a second level of pumice delivered sample TB1-D (SiO2 59.96\%, K2O 1.04\%). Their equivalent chemistry may indicate a single source, most probably associated to the nearby Chachimbiro volcano (Hugá's phase) as well (Bernard et al., 2011), but also possibly related to the Cuicocha volcano. The resulting bulk ages place these events as occurring between $3183 \mathrm{yr}$. cal BP (TB1-5C) and $2226 \mathrm{yr}$. cal BP (TB1-6). The age of the pumice layer is possibly closer to this second age considering that 3 out of 4 ages are really close to each other and coherent with ages obtained around 2240-2450 yr. cal BP by Bernard et al., (2011) for a Chachimbiro eruption. The volcanic fallout sequence continues with a massive basaltic andesitic ash deposit, hereafter called $\beta$ horizon (sample TB1E), which based on its particle size and facies, would come from a proximal source, probably Chachimbiro, although it's chemical composition is quite different. This ash layer is recognized throughout Trench 1 , with horizontal deposition surfaces on both sides of the fault. Its age is estimated at $1579 \mathrm{yr}$. cal BP (bulk; TB1-7C). In trenches 1 and 2, the surface of this ash fall becomes finely laminated in the subsided block at the base of the fault, with locally thin organic soil lenses.

\section{Package " $C »$}

Above the $\beta$ horizon, the sedimentary series is confined to the hanging wall of the fault in trench 1 , and extends over the fault zone in trenches 2 and 3 . Sedimentation is fine to very fine, with volcanic and volcano-sedimentary deposits, and organic soils, which reflect the accumulation of material within the depression caused by the fault activity. 
From the bottom to the top, we recognize first a well sorted sandy level, $50 \mathrm{~cm}$ thick, unconformably relying above the $\beta$ horizon with clear onlaps. The horizon is massive in trench 1 on the periphery of the pond and, on the contrary, has a horizontal or slightly dipping lamination in trench 2 near the outlet of this small basin, suggesting that the level in question corresponds to a runoff event draining the pond. On top of this sandy layer, lies a $\sim 20 \mathrm{~cm}$ thick layer of weathered ashes, reworked in a sandy matrix. The age of this whole body could be bracketed between the deposition of the $\beta$ horizon ( $1579 \mathrm{yr}$. cal BP) and the deposition of the overlying deposits for which the sample TB1-14,5 (charcoal - 1289 yr. cal BP) may provide a better age than sample TB1-14 (bulk $1782 \mathrm{yr}$. cal BP). The charcoal age is preferred according to the often "too-old" bulk age problem encountered in radiocarbon dating of bulk sediments (see Strunk et al., 2020 and references therein) and the absence of known specific studies on the topic in andisols. Laminations within this deposit are deformed and convoluted (soft sediment deformation) close to the edge of the basin by a post-depositional process.

Next, there is a succession of ash deposits interbedded in organic soils. The first ash is fine, probably distal and rhyodacitic to rhyolitic in composition (sample TB1-G: SiO2 $69.5-\mathrm{K} 2 \mathrm{O} 2.01$ ). It is heavily bioturbated by roots that developed during successive soil development. This ash is dated around $1289 \mathrm{yr}$. cal BP (coal - TB1-14.5) and was clearly recognized solely in trench 1 . The $2^{\text {nd }}$ and $3^{\text {rd }}$ ashes have a same Rhyolitic composition (samples TB1F and TB1-H: SiO2 72.8 - K2O 2.85 and 2,75 respectively), meaning that TB1-H most probably corresponds to a reworked deposit of TB1-F. TB1-F is a very fine distal cinerite, while TB1-H is reworked and hence a bit coarser, they may correspond to a Rhylotic volcanic event possibly located in the Eastern Cordillera, where rhyolitic volcanoes are present (Barberi et al., 1988). The basal ash TB1-F is dated 946 yr. cal BP (charcoal - TB1-16C), while the reworked one TB1-H should have been deposited in between $283 \mathrm{yr}$. cal BP (bulk - TB1-17) and $183 \mathrm{yr}$. cal BP (bulk - TB1-18). The age obtained on TB1-17,5 (charcoal - 454 yr. cal BP) within TB1-H being not usable considering the reworked nature of this uppermost ash layer. The structure of TB1F is intimately laminated and deformed in the form of convolute-bedding. TB1-F was recognized within all the trenches, while it is less clear concerning TB1-H.

Finally, the sequence of the pond ends with the current soil dated $183 \mathrm{yr}$. cal BP (bulk - TB1-18). It is noted that, within package $C$, the ages from charcoals and those from soils (bulk) are stratigraphically consistent, ranging between $1289 \mathrm{yr}$. cal BP and 183 yr. cal BP, with the exception of TB1-17,5 (reworked charcoal) and TB1-14 (1782 yr. cal BP), the latter being inconsistently younger than the $\beta$ horizon (1579 yr. cal BP).

\section{Identification and quantification of surface deformations at the trench site}

The three presented trench-walls show evidence of a series of brittle structures consisting in both individualized fault strands and open fissures affecting the exposed sediments, coherent with an episodic rather than creeping character of deformations (McCalpin, 2009). Classical geometric and stratigraphic arguments such as faults sealed by stratigraphic horizons or colluvial wedges associated with fault segments were used to identify single deformation episodes. From this analysis, up to 7 and at least 6 distinct events occurred during the last $\sim 6000$ years. Some of these events are well expressed in the trenches, while other may be more speculative and related to others (table 1). These different events are described hereafter from the most recent to the older one and reported in table 1 as well. Note that all reported faults displacements are measured along fault strands in the 
trenches, and are not taking into account any strike slip component. These faults displacement should then be considered as minimum displacements.

- $\quad \mathrm{E} 1$ is the youngest deformation episode, with the emergence of the F3-2, F4-2 (trench 2) and F4-3 (trench 3) fault strands through the most recent layers (post $283 \mathrm{yr}$. cal BP) and the current soil (post 183 yr. cal BP), and possibly F1-1 in trench 1. In addition, close to Trench T3, there is a slight decimetric topographic counter-slope rise in the downstream sagpond drain that may correspond to the residual trace of this last morphogenic event, also noticeable from the topographic surface along trench 3 (Figure 8). A shift of about the same order ( 5 to $10 \mathrm{~cm}$ ) could be observe along the F4-2 strand, while it is more difficult to quantify for the F4-3 and F3-3, which apparently also registered older events (i.e. E3 and E4). The age of $\mathrm{E} 1$ is compatible with the known $1868 \mathrm{M}^{\sim 7,2}$ and $1955 \mathrm{M}^{\sim} 6$ earthquakes;

- $\quad$ E2 is only found in trench 3. In this trench, F1-3 offsets the F horizon (related to TB1-F sample in trench 1) by a reverse offset of nearly $10 \mathrm{~cm}$. This event then clearly postdates the deposition of the $\mathrm{F}$ horizon (946 yr. cal BP) and should have occurred during the development of the overlying undeformed layer (283 yr. cal BP). However, the possibility of E2 being related to E1 cannot be ruled out. E2 is also compatible with the above-mentioned historical earthquakes;

- $\quad$ E3 is evidenced in trench 3 where the sealing of the F2-3 and F3-3 faults attests to its occurrence during the accumulation of the sedimentary horizon above the $\beta$ horizon, in a range between $1579 \mathrm{yr}$. cal BP and $1289 \mathrm{yr}$. cal BP. The amount of displacement visible in trench 3 is again about $10 \mathrm{~cm}$. In trench 2 , this event may also be evidenced at F3-2, specifically through the differential offset of the $\beta$ horizon and its overlying deposits. However, given the very small amount of cumulative displacement observed along the F3-2 fault strand over the $\beta$ horizon, the observed deformation may also be solely related to E1;

- $\quad$ E4 is determined in all trenches. It first appears as the strong unconformity between the stratigraphic horizons of packages $B$ and $C$, at the top of the $\beta$ horizon. This unconformity reflects an essentially flexural deformation of the deposits, underlined by the tilt of open cracks filled with $\beta$ in trenches 1 and 2 and by retrograde sedimentation in the sagpond marked by successive onlaps (package $C$ ) onto the $\beta$ horizon. In addition, vertical offsets of the ash are clearly visible in the three trenches, measurable in trench 2 where it reaches $\sim 30 \mathrm{~cm}$, and possibly more in trench 1 but with no clear piercing points (at least $50 \mathrm{~cm}$ ). Occurring just after the deposition of the $\beta$ horizon, E4 may potentially be related to the activity of the nearby Chachimbiro volcano. There is however no sedimentological argument to support this hypothesis since no colluvial wedge is preserved. Such argument have for example been proposed by Villamor et al., (2011) to interpret the occurrence of faulting short after de deposition of volcanic fallouts from paleoseismological observations. As for $\mathrm{E} 3$, the event could then be chronologically framed by the end of $\beta$ horizon and the start of the deposit of the package $C$, in a range between $1579 \mathrm{yr}$. cal $\mathrm{BP}$ and 1782 yr. cal BP;

- $\quad \mathrm{E} 5$ is only evidenced in trench 2 where F2-2 shifts the sedimentary sequence by 5 to $10 \mathrm{~cm}$ until the base of the $\beta$ horizon which does not seem affected by faulting. The occurrence of this event may then 
be framed in between TB1-7 (2225 yr. cal BP) and TB1-7C (1579 yr. cal BP). However, the question of the temporal relationship of this event with deposition of the $\beta$ ash arise again. While there are no arguments along F2-2 to answer this question, the presence of open fissures filled with the $\beta$ horizon could represent, following criteria proposed by Villamor et al. (2011), a robust evidence of fallout deposition short after the occurrence of E5;

- $\quad$ E6 is marked only in Trench 1 by the fault termination of F2-1 and F1-1, sealed by the Chachimbiro pyroclastic flow. As for E5, the event may also be related to a known eruption of Chachimbiro volcano (table 1), occurring in that case short before the eruption. But again, there is no additional stratigraphic argument to confirm this hypothesis. The event is therefore framed between $5399 \mathrm{yr}$. cal BP (TB1-4) and $6189 \mathrm{yr}$. cal BP (TB1-9). If we consider the upper limit of the colluvial wedge (TB1-9) as being continuous prior to $E 6$, a shift of $8 \mathrm{~cm}$ could be observed at $F 2-1$. A shift of $\sim 10 \mathrm{~cm}$ of the transition fringe (unit where the sample TB1-3 was collected) could be observed at F1-1;

- $\quad$ E7 is poorly recorded in Trench 1. This event can broadly be bracketed between 5399 (TB1-4) and 7722 yr. cal. BP (TB1-3) and could be represented by the colluvial wedge deposit dated at $6189 \mathrm{yr}$. cal BP (TB19). This age probably predates the event, considering that the bulk age we obtained should represent the age of the andisol trapped in the wedge. Hence, the age of E7 could be precised as occurring in between 5399 yr. cal. BP and 6189 yr. cal. BP. A minimum displacement $\sim 10 \mathrm{~cm}$ of the transition fringe could be observed at F1-1 and of $37 \mathrm{~cm}$ along F2-1, but is most probably underestimated.

\begin{tabular}{|c|c|c|c|c|}
\hline \multirow[t]{2}{*}{ Paleoseismic event } & \multicolumn{2}{|c|}{$\begin{array}{l}\text { Datings (median calibrated ages) } \\
\text { An underlined date indicates the best stratigraphic solution }\end{array}$} & \multirow{2}{*}{$\begin{array}{l}\text { Offset (i.e. without strike- } \\
\text { slip component) }\end{array}$} & \multirow{2}{*}{$\begin{array}{l}\text { Relation to contemporary volcanic } \\
\text { eruption } \\
\text { (red: possible ; green: probable) }\end{array}$} \\
\hline & Postdates (in yr. Cal. BP) & Predates (in yr. Cal. BP) & & \\
\hline E1 & 283 (and probably 183) & - & $>5-10 \mathrm{~cm}($ trench 2$)$ & No known eruption \\
\hline E2* (possibly related to E1) & 283 & $183 ?$ & $\sim 10 \mathrm{~cm}$ (trench 3$)$ & No known eruption \\
\hline E3 & 1579 & 1289 & $10 \mathrm{~cm}$ (trench 3$)$ & No known eruption \\
\hline E4 & $\underline{1579}$ & 1289 & $\begin{array}{l}30 \mathrm{~cm}(\text { trench } 2) \\
>50 \mathrm{~cm}(\text { trench } 1)\end{array}$ & Chachimbiro (this study) \\
\hline E5 & 2225 & $\underline{1579}$ & $5-10 \mathrm{~cm}$ (trench 2) & Chachimbiro (this study) \\
\hline E6 & 6189 & $\underline{5399}$ & $\sim 18 \mathrm{~cm}($ trench 1$)$ & $\begin{array}{l}\text { Chachimbiro satellite dome } \\
\text { (Bernard et al., 2011, 2014) }\end{array}$ \\
\hline E7 & $\underline{6189}$ & 5399 & $>47 \mathrm{~cm}($ trench 1$)$ & No data available \\
\hline
\end{tabular}

TABle 1 : tABle SUMmARIZING THE CHARACTERISTICS OF PALEOEARTHQUAKES DERIVED FROM TRENCH ANALYSIS. THE POSSIBLE RELATIONSHIPS WITH KNOWN VOLCANIC ACTIVITY IS ALSO REPORTED.

The timing of the interpreted events is rather irregular, apparently becoming more frequent as approaching the present. The fine grained sedimentation within the pond, which allowed identifying recurring events in the uppermost layers of trenches 2 and 3 may however bias this result. Indeed, if package $C$ constitute a remarkable recorder of successive events, packages B and A are more homogenous, with few well identified stratigraphic markers. This hamper the identification of all the events that might have occurred in the older times in trench 1. Concerning the total amount of deformation associated with these events, it is a difficult parameter to quantify directly from these trenches:

- Faults in trench 1 show a significant cumulative vertical deformation of the oldest colluvial deposits (Package A). Fault strand F1-1 registered at least $65 \mathrm{~cm}$ of cumulative displacement, while a minimum 
of $45 \mathrm{~cm}$ displacement can be measured along F2-1. Package $A$ was then shifted by a minimum of 110 $\mathrm{cm}$;

- Many fault strands in trenches 2 and 3 highlight a relatively limited amount of vertical deformation, failing to explain the total amount of sediments captured in the pond, representing at least $1,5 \mathrm{~m}$ of sediments deposited in 1579 years if we consider sediments lying above the $\beta$ horizon in trench 1 (i.e. corresponding to the 4 latest events);

In addition to these points, we note that the peculiarity of the andisols strongly limits their use as reliable markers of tectonic displacements on each side of a fault. Indeed, andisols continuously develop on ash-falls deposited along preexisting topographies, hence possibly mimicking previous offsets. In addition, ash-fall deposits could also have been displaced and accumulated according to several factors such as the action of winds, rains etc... Quantifying the amount of deformation registered along this fault segment is then not straightforward.

The only reliable marker that would allow quantifying long term deformation and slip rates is package $A$ in trench 1 if we consider that the deformation registered along this fault segment occurred after the deposition of this layer. Such a hypothesis being supported by the fact that the amount of deformations registered all along this fault segment at surface is rather uniform whatever the encountered lithologies (Pleistocene and Holocene in age). The top of Package $A$ was recognized at a depth ranging from 1 to $1.5 \mathrm{~m}$ at the footwall of the fault in trench 1, while Saqui (2019) identified its depth at $\sim 6 \mathrm{~m}$ at its hangingwall after the analysis of ground penetrating radar measurements performed along the trace of the trenches. A local cumulative vertical separation of 4.5 to 5 meters could then be estimated during a period ranging from $11202 \mathrm{yr}$. cal BP (TB1-2) and 7722 yr. cal BP (TB13). The most recent age being a minimum age because the alteration fringe lying onto the alluvial basal layer developed over a long period of time during which faulting could have occurred. We can then propose a Holocene first order vertical separation rate of $0.4-0.65 \mathrm{~mm} / \mathrm{y}$ along this fault segment of the BFS. Finally, the general pattern of deformation is coherent with dominant vertical motions (geometry and displacement), with a noticeable but most probably less significant horizontal component. However, the kinematics of the fault as deduced from trenching remains questionable and will be discussed in the following 


\section{5- Discussion}

In the following paragraphs, hypothesis concerning the kinematic, age and origin of deformations are discussed in light of our newly acquired data.

\section{General structure of the BFS and age of surface deformations}

The availability of the $4 \mathrm{~m}$ spatial resolution DSM allowed extending the mapping of the BFS along a $\sim 25 \mathrm{~km}$ band covering the Cretaceous bedrock cropping out in the Billecocha plateau as well as the Cotacachi and Chachimbiro volcanoes (Figure 2). This first observation means that bedding fault slip along the near vertical cretaceous strata outcropping within the plateau, as envisaged by Ego et al., (1996a) could not entirely explain the spatial extension of the BFS. Our mapping show that the overall shape and orientation of the BFS is superimposed with those of the Pujilí fault system running through the western Cordillera (Figure 2), which means that the BFS essentially developed along this major inherited structure. Although the general shape of BFS suggests that it is a relatively vertical and deeply rooted fault system, there are few data (i.e. geological, seismological, geophysical) supporting that the active segments of the BFS are rooted on the Pujili fault at crustal scale. Indeed, the geometrical relation between the BFS and the Pujili fault at depth will depend on the involved deformation processes, discussed in the following sections.

The overall surface morphology of the Billecocha plateau and surroundings is young and mainly results from Pleistocene to Holocene processes, either volcanic or climatic. Concerning the BFS, we considered that vertical deformations mapped at surface are mainly post-glacial in age in order to propose fault slip-rates (section $4 \mathrm{~b}$ ). We hereafter discuss the possibility of longer term deformations being registered and/or preserved along the studied faults, which may as a consequence lower these inferred slip-rates. In this light, we need to tackle to complementary questions: (1) are the quantified vertical deformations containing a signal from pre-existing scarps, and (2) could pre-existing scarps have been eroded by glaciers or buried below volcanic or glacial/postglacial sediments?

For the first question, if we consider that slip-rates are rather constant over time, one could expect the development of significantly different cumulative deformations depending on the age of the affected geological formations. This is for example not the case along the longer fault segment of the BFS that crosses the plateau and the surrounding Cotacachi and Chachimbiro volcanoes, and where we observe that vertical deformations are sharp, continuous and rather constant over the entire fault segment length (see Figure 10 and measurement points provided in supplementary materials). However, these are punctual observations and the possibility that part of the deformations could be inherited cannot be totally discarded.

For the second question, the hypothesis of pre-existing scarps buried below recent sediments may only be valid in a few areas where marshes and ponds have developed and where morainic cordons were deposited. Elsewhere, the Holocene cover is not thick enough to burry significant inherited deformations (see Figure 9 for example). The hypothesis that pre-existing scarps may have been eroded by glaciers is harder to discard, essentially because few data are available concerning the last glacial maximum in Ecuador (see Rodbell et al., 2009 and references therein). In the Billecocha area, Ego et al. (1996a) is the only source of information. They 
estimated an ice-cap thickness of $120 \mathrm{~m}$ covering the plateau, based on morphological arguments. This seems in line with what we observed from the DSM analysis, where the lowest observed frontal moraines reach altitudes as low as $3200 \mathrm{~m}$ a.s.l., meaning that only short glaciers have flowed down the plateau, toward the IAV. This is also coherent with what was observed in Ecuador, where glaciers of the western Cordillera never reached altitudes lower than $3000 \mathrm{~m}$ a.s.l. during the Quaternary (Clapperton et al., 1997), which means that the ice caps that covered parts of the cordillera, including Billecocha, had a relatively limited extension and that the IAV was free of ice. In the Billecocha area, the ice-cap seems to have had a fairly limited erosive power given the short extension and limited thickness of moraines and other fluvio-glacial sediments observed in the area. This may also be confirmed by well-preserved pre-existing morphologies, as for instance the undulated surface of ancient lava flows, such as the one presented in Figure $3 b$.

Considering these points, we suggest that:

- The broader scale geometry of the BFS is controlled by the inherited Pujili fault at the surface. But the geometry at depths of the BFS remains unknown;

- The longest scarp observed along the BFS is young, possibly Holocene in age, hence associated with a vertical throw rate ranging from 0.4 to $0.65 \mathrm{~mm} / \mathrm{y}$ (see section 4);

- Maximum cumulative vertical throws across the overall BFS, inferred from our morphological analysis reaches $34 \pm 6$ meters, which may be converted into a first order vertical deformation rate not exceeding 2,3 to $3,3 \mathrm{~mm} / \mathrm{yr}$ if we consider a global post-glacial age for these (post 12ky. BP).

\section{Kinematic of surface deformations along the BFS}

Both morphological and paleoseismological investigations confirmed the dominant vertical expression of deformations at the surface. The horizontal component we noticed within the paleoseismological trenches has not been highlighted from the morphological analysis, hence questioning our ability to detect horizontal deformations from the DSM analysis. One explanation could be that the available DSM is more sensitive to vertical motions because of its better vertical accuracy (decimetric) than spatial resolution (4 meters). One other may arise from the fact that markers of vertical deformations in active tectonic landscapes are often easier to evidence and better preserved from erosion in comparison to horizontal ones. However, such a horizontal component must be relatively tenuous if we consider that it was not even detectable in longer-term landscape features, which should have registered more significant cumulative lateral deformations (e.g. lava flows in Figure 3b). As a comparison in an analogue high altitude environment in Ecuador, equivalent morphological and geological markers clearly record the Holocene lateral component of fault motion in both Pisayambo (Champenois et al., 2017) and Igualata (Baize et al., 2020) areas.

The major fault strands observed within the trenches and affecting the topography are nearly vertical, and at first glance compatible with transtensional to purely normal motions. However, some localized reverse motions observed in trenches and farther from the trench site are making this interpretation questionable. Within the paleoseismological trenches, reverse motions (Trench 3, Figure 8) are limited and located in front of the fault 
scarp, which is not uncommon in extensional environments and therefore is not incompatible with a normal behavior of deformations along the scarp. However, some other observations performed in road cuts away from the trench site are less compatible with an overall extensional environment. One of these observations is presented in figure 9 , where a reverse fault highlighting a comparable strike compared to the trenched fault scarp outcrops. It affects both the cretaceous basement and the base of package $B$ during a probable single event. The first level of white pumices corresponds to sample TB1-B in trench 1 (Figure 7) and is not deformed. In addition, there is no clear topographic imprint related to reverse faulting on top and around the outcrop. Radiocarbon dating of the Holocene thrusted unit allow bracketing the occurrence of the event in between 8792 yr. cal. BP (sample RF1, Figure 9) and 5399 yr. cal. BP (i.e. age of the white pumices in trench 1, sample TB1-4, Figure 7). The position of the reverse fault with respect to the topography, right at the crest line separating the plateau from the slopes toward the IAV suggests that it is tectonic in origin and not related to other processes such as gravitational deformations. Furthermore, the clear involvement of the basement as well as the distance of this outcrop from the normal fault scarps indicates that this deformation may not be interpreted as a reverse secondary faulting related to the activity of the main fault scarp. This surface rupture then probably occurred within a compressive regime, which, given the similar orientation of the faults, may not be compatible with the one that led to develop the BFS.

Three possibilities are then arising, considering that pure strike-slip kinematic can be ruled out along the studied fault segments:

- Vertical motions observed along the BFS are associated with extension and normal kinematics. Reverse motions observed away from the mapped faults are secondary evidences related to normal faulting or not related to tectonics. We consider this hypothesis as the most unlikely;

- Vertical motions observed along the BFS are associated with compression along near vertical inherited fault planes. In this case, reverse motions observed away from the mapped faults are compatible;

- Normal and reverse motions coexist in the Billecocha area at the scale of the Holocene.

Given the difficulty of favoring one of these last two hypotheses, we hereafter discuss the deformation processes that may support them, taking into account the data available in the region. 


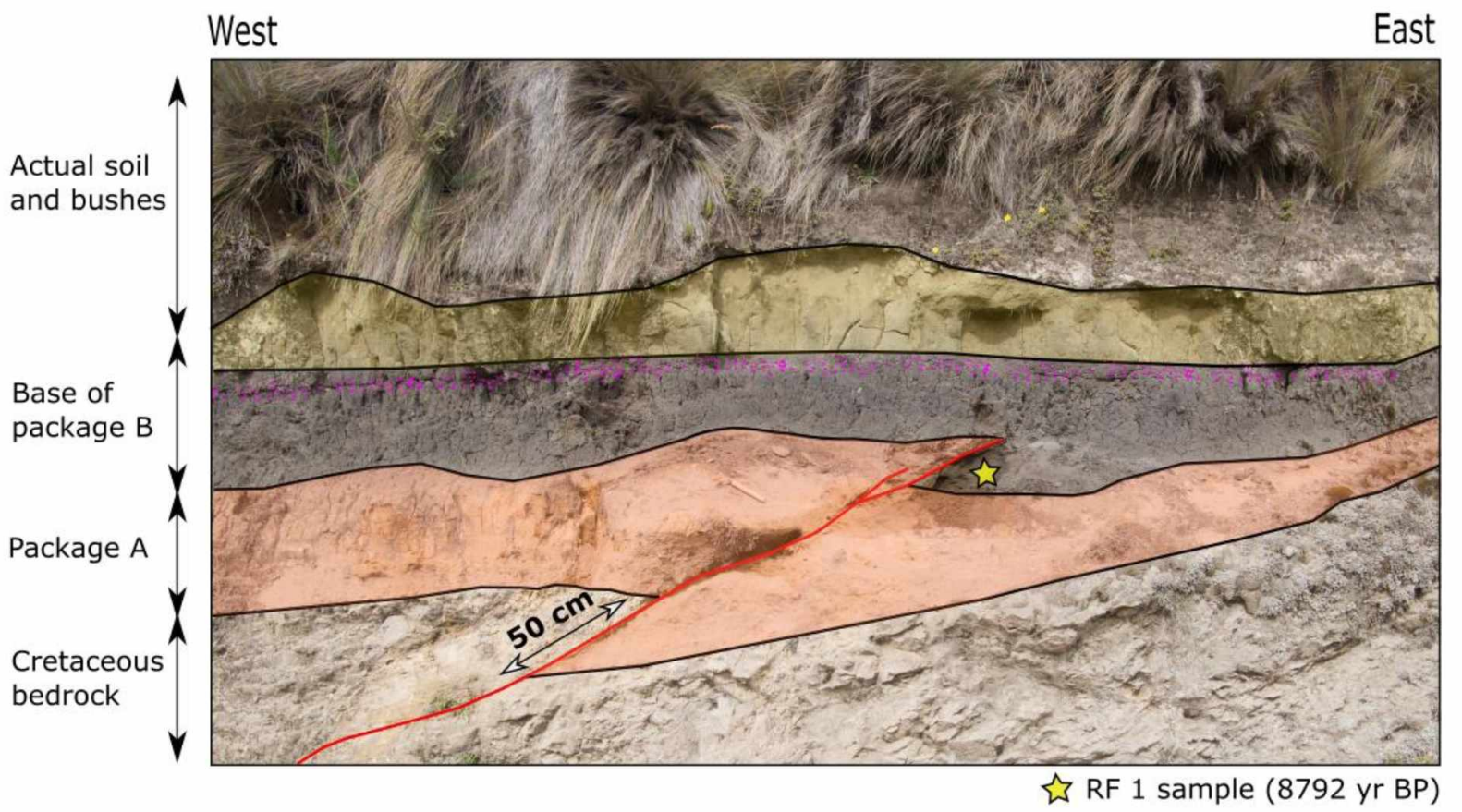

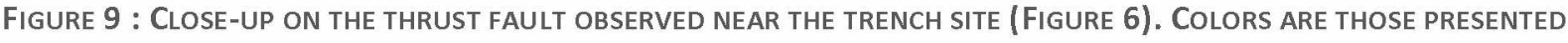
IN THE TRENCH SECTIONS (FIGURE 7 AND 8). THE YELLOW STAR REPRESENTS THE LOCATION OF THE C14 SAMPLE.

\section{Origin of the observed deformations}

\section{Purely tectonic processes}

As pointed out in section 3, the actual stress regime expected in the area is related to E-W shortening (Vaca et al., 2019), leading to reverse and right lateral strike slip motions along regional faults (Alvarado, 2012). The wider Billecocha area is unfortunately not covered by GPS measurements, but this expected E-W shortening is coherent with what is observed further south in the Quito region (Alvarado et al., 2014, Marinière et al., 2020).

In this context, a purely normal stress regime is hardly compatible with regional seismotectonic data (GarcíaVillarruel, 2018; Vaca et al., 2019) and may also not explain the occurrence of reverse faulting in the area. On the contrary, a purely reverse stress regime, more compatible with seismotectonic data, hardly explain the occurrence of primary vertical ruptures along straight and near vertical fault segments. Strike slip faulting then represents the better candidate, potentially compatible with the variety of faulting we evidenced. In addition, we observed that fault scarps within the plateau are mostly east facing (red dots in Figure 10) whereas those affecting the slope toward the IAV are mostly west facing (blue dots in Figure 10), then compatible with a local releasing bend in a wider right lateral strike slip fault system. However, the continuity of this fault system both north and south of Billecocha is difficult to evidence. For instance, the Huayrapango fault, supposed as being the continuation of the BFS toward the south-west, seems to highlight lower slip-rates (probably less than $1 \mathrm{~mm} / \mathrm{yr}$. according to Egüez et al., 2003).

Another model that would possibly explain vertical deformations located along inherited faults and bedding planes is flexural slip (Yeats, 1986). In this model the BFS would act as a secondary structure to a main primary 
thrust fault (McCalpin et al, 2020) which is still not recognized at present. By making an analogy with what is observed further south in Quito (Alvarado et al., 2014) and Latacunga (Fiorini and Tibaldi, 2012; Baize et al., 2020), an east verging low angle thrust fault outcropping within the slope toward the IAV, or within the IAV where some reverse fault systems have already been mapped (Alvarado, 2012, see Figure 2), may be envisaged. This model has the advantage to be compatible with the rare occurrence of reverse faulting within the plateau, where near vertical structures (i.e. inherited fault planes and/or bedding planes) won't be well oriented with respect to a regional horizontal compressive stress regime. It seems however not compatible with the occurrence of both east and west facing scarps, considering that these should occur in case of the presence of folds, presenting both east and west dipping discontinuities.

In any case, the full tectonic origin of surface deformations recorded along the BFS remains not fully satisfactory.

\section{Volcano-tectonic interactions}

Surface deformations observed along the BFS, crosscutting active volcanoes, could also be related to volcanotectonic interactions. Indeed, faults in volcanic regions may receive and respond to stresses from both tectonic and magmatic processes (Roman and Heron, 2007), each of them being able to either promote or inhibit the triggering of volcanic activity and/or earthquakes (e.g. MacQueen et al., 2020), which makes the volcano-tectonic interaction a difficult process to characterize.

In the Ecuadorian volcanic arc, such interactions have for example been described to explain both the long term evolutions of faults and volcanoes (e.g. Bablon et al., 2019 ; Andrade et al., 2019) and the occurrence of seismic swarms associated with volcanic processes (e.g. Aguilar et al., 1996; Legrand et al., 2002 ; Ebmeier et al., 2016). However, there are no known major crustal earthquakes and surface ruptures along active faults clearly related to volcanic activity in Ecuador. Only the seismic nest located in the Pisayambo area (Eastern Cordillera, Figure 1), which was suspected to be related to magmatic processes (Aguilar et al., 1996), produced a shallow right lateral surface rupturing earthquake (M5, Champenois et al., 2017) along a segment of the CCPP fault system.

Despite the few available data allowing to assess the potential influence of active volcanoes on the Holocene activity of the BFS, a number of points can however be noted:

- Instrumental seismicity rates and earthquake magnitudes are low within and around Billecocha. Temporary seismological networks however revealed the occurrence of low magnitude volcanotectonic earthquake swarms at the eastern flanks of the Chachimbiro and Cotacachi volcanoes, highlighting a possible right lateral strike slip tectonic component, even at shallow depths (CórdovaRegalado, 2013 ; García-Villarruel, 2018). The microseismic activity a Billecocha plateau remains however poorly known;

- The two major historical earthquakes that struck the area in 1868 and 1955, potentially recorded in our trenches, are not known to have been preceded or followed with any sign of volcanic activity. Of course this doesn't mean that deep volcanic processes may not have participated in triggering those events; 
- From our paleoseismological data, probably 1 and possibly 3 out of 7 paleoseismic events may have occurred within an eruptive phase of the Chachimbiro volcano (table 1). Beside, a given number of known eruptions are not related to paleoearthquakes along the trenched fault segment. This is for example the case for the Cuicocha VEI 5 eruption, the biggest volcanic eruption known so far in the region during the Holocene. But this needs to be confirmed by trenching other fault segments of the BFS. However, this ratio is rather consistent with what was observed by Villamor et al., (2011) in the Taupo rift (New-Zealand) from a compilation of paleoseismological data, where $30 \%$ of the fault ruptures they observed occurred when a volcano was erupting;

- In many reported cases over the world, surface faulting related to volcano-tectonic processes occur during magma intrusions (e.g. Dumont et al., 2016) or while volcanoes are in activity (e.g. De Novellis et al., 2019 ; MacQueen et al., 2020;). In the Billecocha area, Chachimbiro and Cotacachi volcanoes (as well as other surrounding volcanoes) have not been erupting in historical times, but there are no available data allowing to evidence possible deep magmatic intrusions during the same period.

- The existence of active volcanism in the Billecocha area doesn't provide definitive information on the kinematic of the surrounding faults. While active volcanism usually require an extensional state of stress in the crust, volcanism occurs also in compressional tectonic settings associated with reverse and strikeslip faulting (Galland et al., 2007; Tibaldi et al., 2009). The latter cases are for example characteristic of the Reventador volcano in Ecuador (Tibaldi, 2008).

- The surface expression of faults at the surface in Billecocha is a unique case in Ecuador, whereas many active volcanoes are present in the close vicinity of active faults and where volcano-tectonic processes have been evidenced as mentioned earlier.

Considering these points, it is clear that volcano-tectonic interactions cannot be ruled-out to explain at least part of the surface deformations observed along the BFS.

\section{Non-tectonic processes}

A third hypothesis would imply the contribution of non-tectonic processes, mainly post glacial unloading or gravitational deformations, as proposed by Ego et al., (1996a).

Concerning the post-glacial unloading hypothesis, favored by Ego et al., (1996a), it is known to result in fault slip along inherited discontinuities during single or multiple seismic events (e.g. Ustaszewski et al., 2008 ; Mattila et al., 2019) or in transient fault slip-rates increases along active faults (Hampel, 2017 and references therein, DuRoss et al., 2020). However, the influence of post-glacial unloading on fault activity is generally thought to be restricted to some thousands of years after the deglaciation, being as short as the original ice-cap thickness is limited (Hampel and Hetzel, 2006). In Billecocha, where the ice-cap was supposedly thin ( $120 \mathrm{~m}$ thick, Ego et al., 1996a), the recurring character of paleoseimic events evidenced in trenches during the last $\sim 6 k a$, the last of them being historical (post $285 \mathrm{yr}$. cal BP), does not entirely fit with this model, which implies that the influence of the deglaciation ended short after the deglaciation phase. However, available data are insufficient to rule out an enhanced slip-rate along the BFS during the postglacial period. 
The last envisaged hypothesis involves the contribution of gravitational deformations. The spatial extent of surface deformations revealed in Billecocha however implies to consider a model compatible with the involvement of the entire slope from the Billecocha plateau toward the IAV. In this context, 'sackung' or 'deep seated gravitational slope deformations' (DSGSD, see Panek and Klimes, 2016 for a review on such phenomena), signing the large-scale lateral spreading of rock masses, present morphological expressions comparable with what is observed along the BFS. It mainly consists in gravitational faults that dip steeply into mountain ridges, resulting in the formation of morphological signatures such as ridge top depressions or "graben-like" features and counterscarps. The spatial extent of such phenomena is usually kilometric (such as in figure $3 e$ ) to plurikilometric (e.g. Jarman et al., 2014; Jomard et al., 2014), however rarely reaching a length comparable to the BFS. These gravitational deformations are observed in all kind of geological contexts, but most of them are reported in paraglacial (e.g. Ballantyne, 2002) and tectonically active environments (McCalpin, 2009). In the latter case, dynamic loading such as earthquake shaking is considered as a possible triggering or accelerating mechanism (Gutierrez et al., 2008; McCalpin, 2009), but DSGSD may also develop directly along active faults (e.g. Ustaszewski et al., 2008; McCalpin et al., 2020).

With the aim to test this hypothesis, we densified the number of scarp-heights measurements performed in Figure 5 along the BFS (from 95 to 201 measurements), hereafter attributing a positive displacement value for the east facing scarps and a negative to the west facing ones (Figure 10). Finally, we performed an interpolation between those points in order to recover and discuss their spatial repartition with respect to the main relief (see details in supplementary materials). Our main observation is that the crest separating the plateau from the slopes toward the IAV roughly coincides with a transition zone between east and west facing scarps, except for a clear outlier at the northern edge of the BFS, already identified in Figure $3 e$ as a localized and well developed DSGSD locally enhancing vertical deformations. Such a spatial repartition allows to highlight that the relief has a significant influence in controlling the direction of vertical motions observed along the BFS, meaning that at least part of these deformations could be gravitational in origin, as it was observed in figure $3 \mathrm{e}$, but at a much wider scale. However, over the two main processes (i.e. paraglacial or active tectonics) leading to the development of such wide gravitational deformations, it is difficult to favor a hypothesis among the other, especially concerning the triggering of the DSGSD. Concerning the most recent period, the dynamic loading by earthquakes or volcanic eruptions is however coherent with the episodic nature of the ruptures revealed by the paleoseismological analysis. In Billecocha, we then propose that part of the deformations developing on inherited structures (mainly the Pujilí fault system and possibly along some vertical bedding planes) could be gravitational in origin. However, such a process is not compatible with the observation of reverse faulting as observed near the crests of Billecocha. 


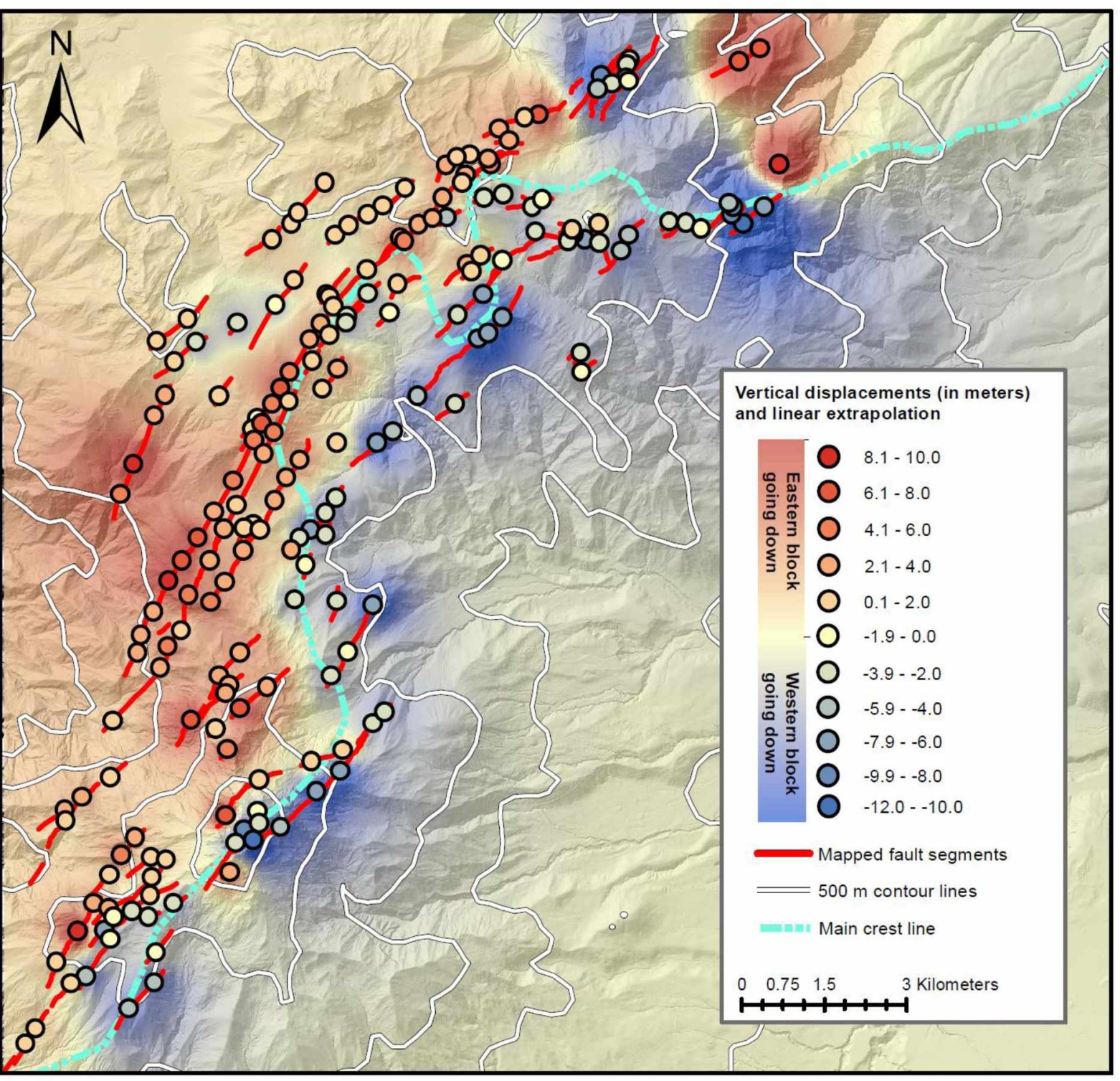

Figure 10 : Vertical meAsurements PERFormed ALONG the BFS AND DERIVEd FRom the BuckNAM ANd ANDERSON (1979) METHODOLOGY AT EACH POINT (TOTAL OF 201 MEASUREMENT POINTS). A BLUE COLOR REPRESENTS A WEST FACING SCARP WHILE A RED DOT REPRESENTS AN EAST FACING SCARP, THE DENSITY OF THE COLOR DEPENDS ON THE QUANTITY OF DEFORMATION (LIGHT-SMALLER, DARK-BIGGER). A SPATIAL INTERPOLATION OF THESE MEASUREMENTS IS DRAPED ONTO THE DSM DERIVED HILLSHADE. THE MAIN CREST LINE WAS MANUALLY DIGITIZED AFTER CALCULATING DRAINAGE PARAMETER, MAINLY THE STRAHLER INDEX, WITH THE QMORPHOSTREAM TOOL (TEBANO ET AL., 2017) IN QGIS. CONTOUR LINES WERE SMOOTHED FROM THE 4M DSM, DOWNSAMPLING THE TOPOGRAPHY WITH QGIS TO A 100M RESOLUTION.

Among the above listed hypothesis, there is apparently not a single process obviously explaining our observations. A compound origin of deformations is then most probably mandatory to reconcile our observations:

- Evidence of reverse faulting and slight horizontal movements are compatible with a mainly transpressive active tectonic regime registered along a near vertical inherited fault zone, in coherence with regional neotectonic and seismotectonic data (Egüez et al., 2003; Alvarado, 2012). In this context, near vertical inherited faults of the BFS are unfavorably oriented with respect to the expected E-W 
maximum horizontal stress axis orientation (Vaca et al., 2019). The tectonic deformation rate accommodated along those faults may be very slow and distributed, explaining why there are no cumulative long term reverse or strike slip field evidence. The possibility that the BFS acts as a secondary structure to a bigger unknown reverse fault, outcropping within the slopes toward the IAV, shall also be considered; as well as transcient volcano-tectonic interactions that may lead to sporadically modify the local tectonic stress field;

- The main vertical signature of the BFS is compatible with gravitational processes occurring along an inherited tectonic structure. However, the source of such gravitational deformations may come from different processes acting at different timescales, from glacial unloading during the early Holocene, to volcanic and earthquake triggering.

Finally, considering the large uncertainties related to each of these possible phenomena, and while waiting to be able to access new datasets. One should regard the BFS as the morphological signature of a highly fractured inherited medium to an active environment where tectonic, volcanic and climatic processes are at play. As an example, gravitational deformations enhancing the geomorphic expression of active faulting in an active volcanic area is for example suspected in Peru in the Huambo-Cabanaconde area (Costa et al., 2020).

\section{Could the BFS be the source of 1868 Ibarra earthquake?}

Given that a possible tectonic origin of scarps and deformations along the BFS has been inferred during this study, we finally discuss the hypothesis of this fault system to be the source of the 1868 lbarra earthquake. This is of particular significance in a seismic hazard perspective.

Trenches across the main fault segment of the BFS allowed evidencing an episodic behavior of the registered deformations. The observation of colluvial wedges in trenches as well as brittle deformations and soft sediment deformations in package $C$ is in addition compatible with a coseismic origin of deformations (McCalpin, 2009). Then, are these coseismic evidence related to primary or secondary faulting? There are many examples of coseismic surface deformation observed along the primary rupture (i.e. the surface rupture is the emergence of the source of earthquake), or secondary ruptures (i.e. the surface rupture is associated with a splay or parallel segment to the primary fault, or to a remote active fault) (Baize et al., 2020 and references therein), or even nontectonic structures such as during the activation of DSGSD features (Gutiérrez et al., 2008; McCalpin et al., 2020).

The age of the E1 \& E2 events (post $283 \mathrm{yr}$. cal BP) are compatible with the occurrence of the lbarra earthquake in 1868. A decimetric vertical displacement associated with the last event affects both the topography along the main fault scarp and sediments in the trenches, without noticeable lateral motion. Hence, even in considering that this vertical deformation would be linked to primary surface faulting, it is small in comparison from what could be expected for such an event of estimated magnitude $\sim 7,2$ using empirical relationships (e.g. Leonard, 2010), so that this fault segment may not constitute alone the primary source of this earthquake. This last hypothesis being valid if there are no strong lateral variations of slip observed along the fault segment, which is the case over the few kilometers we were able to follow on the field. 
However, the possibility that this last event do represent the surface expression of the 1868 earthquake source cannot be ruled out: (1) deformation could have been distributed along other unstudied faults segments of the BFS; and (2) the studied fault segment could act a secondary structure structurally related to a bigger but unknown one, such as it was observed along secondary faults and folds after the 1999 Chi-Chi earthquake (Chen et al. 2007),

\section{6- Concluding remarks and needs for future investigations}

Billecocha is a high altitude and remote area, explaining why few studies have been dedicated to its analysis, from the pioneer work by Ego et al., (1996a) until this new study. However, this area deserves more attention because we believe that it is one of the rare known places where gravitational, volcanic and tectonic phenomena are intimately related to each other. Indeed, our morphological and paleoseismological analysis of the Billecocha Fault System allowed proposing a compound origin to explain the spectacular late Pleistocene to Holocene reactivation of a segment of the inherited Pujili fault system. While the main geomorphological signature of the BFS is most probably related to deep seated gravitational processes, a more subtle imprint of active faulting was also identified at the trench site, compatible with the regional transpressive seismotectonic context (Alvarado, 2012; Vaca et al., 2019).

Among the formulated hypothesis concerning the origins of the studied deformations, the possibility that the BFS acts as a secondary structure to an unknown tectonically active one has our preference. It has the advantage of being compatible with the occurrence of rare tectonic secondary deformations along the BFS as well as the low instrumental seismicity recorded in the area. It also has the advantage of being compatible with the occurrence of active fault related gravitational deformations (Audemard et al, 2010; McCalpin et al, 2020) and the development of a large DSGSD (Jomard et al., 2014). If so, we could envisage two possibilities concerning the location of the primary active fault:

- The primary fault lies within the Billecocha plateau, being eventually one of the unstudied segments of the BFS, since our paleoseismological study focused only on what we considered to be the main fault of the BFS. It then asks for more paleoseismological investigations along other segments of the BFS in order to (1) confirm or not the synchronicity of the deformations we observe over different segments and (2) possibly unveil the primary active fault;

- The primary source is blind and may outcrop away from the Billecocha area. In an analogy with the Quito fault system located further South of Billecocha (Alvarado et al., 2016, Marinière et al., 2020), a low angle east verging thrust fault outcropping east of the BFS toward or within the IAV could be envisaged. In this light, known evidences of active reverse faulting occurring within the IAV (Ego et al., 1996a, Egüez et al., 2003, Alvarado, 2012) should be further studied.

In both cases, an enhanced coverage of seismologic and geodetic networks, especially west of the BFS is mandatory in order to monitor and better characterize the seismotectonic behavior of the area as well as the possible volcano-tectonic interactions. 
More generally, the cumulative deformation measured along the BFS cannot be used to derive fault slip rates that could further be used in seismic hazard calculations. It then recalls that slip-rates derived from the morphological analysis of lineaments shall be cautiously estimated, especially in such mountainous areas. In addition, the determination of surface displacements that may be retrieved from the paleoseismological investigations at the BFS cannot be representative of those occurring along the primary seismogenic source, as existing scaling laws only take into account observations on the main ruptures (e.g. Leonard, 2010). However, this type of secondary structure allow an indirect identification of paleoearthquakes that struck the area (Gutiérrez et al., 2008) and would potentially have been generated by the main structure (Cinti et al., 2019, McCalpin et al., 2020). In this light, at least 6 and possibly 7 strong events have struck the area during the Holocene, some of them possibly in relation with volcanic eruptions, and the last being compatible with the 1868 Ibarra earthquake.

\section{Acknowledgments}

Field work expenses were funded by the Instituto Geofisico, Escuela Politecnica Nacional de Quito, the "Laboratoire Mixte International Séismes et Volcans des Andes du Nord" of "Institut pour la Recherche et le Développement" (LMISVAN), by the "Agence Nationale pour la Recherche" through the ANR-REMAKE project (Grant Number: ANR-15-CE04-0004), and by proper funds from the "Institut de Radioprotection et de Sûreté Nucléaire".

We sincerly thank Dr. Maria Ortuño and Dr. Nicola Litchfield for their thorough review of our paper, and who greatly contributed to improve our interpretations. We also greatly thank Dr. Carlos Costa who really helped us publishing this study during those difficult COVID-19 times.

We finally warmly thank the people of the Reserva Cotacachi Cayapas, who allowed us working there and provided help during our field investigations.

\section{References}

Agliardi, F., Crosta, G., \& Zanchi, A. (2001). Structural constraints on deep-seated slope deformation kinematics. Engineering Geology, 59(1-2), 83-102.

Aguilar, F. C. (1868). Catástrofe del 16 de agosto de 1868. In Anales de la Universidad Nacional de los Estados Unidos de Colombia (Vol. 1, No. 4, pp. 422-428).

Aguilar, J., Chatelain, J. L., Guillier, B., \& Yepes, H. (1996). The Pisayambo, Ecuador, seismicity nest: towards the birth of a volcano?

Almeida M (2016) Estudio Petrográfico y Geoquímico del Volcán Cotacachi - Provincia de Imbabura. Ecuador, EPN, Quito 
Almeida, M., Bablon, M., Andrade, D., Hidalgo, S., Quidelleur, X., \& Samaniego, P. (2019). New constraints on the geological and chronological evolution of the Cotacachi-Cuicocha Volcanic Complex (Ecuador). In 8th International Symposium on Andean Geodynamics (ISAG).

Alvarado, A. (2012). Néotectonique et cinématique de la déformation continentale en Equateur. PhD thesis: University of Grenoble Alpes.

Alvarado, A., Audin, L., Nocquet, J. M., Lagreulet, S., Segovia, M., Font, Y., ... \& Jarrin, P. (2014). Active tectonics in Quito, Ecuador, assessed by geomorphological studies, GPS data, and crustal seismicity. Tectonics, 33(2), 6783.

Alvarado, A., Audin, L., Nocquet, J.M., Jaillard, E., Mothes, P., Jarrín, P., et al. (2016). Partitioning of oblique convergence in the Northern Andes subduction zone: Migration history and the present-day boundary of the North Andean Sliver in Ecuador. Tectonics. doi:10.1002/2016TC004117

Andrade, S. D., van Wyk de Vries, B., \& Robin, C. (2019). Imbabura volcano (Ecuador): The influence of dippingsubstrata on the structural development of composite volcanoes during strike-slip faulting. Journal of Volcanology and Geothermal Research, 385, 68-80.

Audemard, F. A., Beck, C., \& Carrillo, E. (2010). Deep-seated gravitational slope deformations along the active Boconó Fault in the central portion of the Mérida Andes, western Venezuela. Geomorphology, 124(3-4), 164177.

Bablon, M., Quidelleur, X., Samaniego, P., Le Pennec, J. L., Audin, L., Jomard, H., ... \& Alvarado, A. (2019). Interactions between volcanism and geodynamics in the southern termination of the Ecuadorian arc. Tectonophysics, 751, 54-72.

Bablon, M., Quidelleur, X., Samaniego, P., Le Pennec, J. L., Santamaría, S., Liorzou, C., ... \& Eschbach, B. (2020). Volcanic history reconstruction in northern Ecuador: insights for eruptive and erosion rates on the whole Ecuadorian arc. Bulletin of Volcanology, 82(1), 1-23 Baize, S., Audin, L., Winter, T., Alvarado, A., Moreno, L. P., Taipe, M., ... \& Yepes, H. (2015). Paleoseismology and tectonic geomorphology of the Pallatanga fault (Central Ecuador), a major structure of the South-American crust. Geomorphology, 237, 14-28.

Baize, S., Audin, L., Alvarado, A., Jomard, H., Bablon, M., Champenois, J., ... \& Le Pennec, J. L. (2020a). Active Tectonics and Earthquake Geology Along the Pallatanga Fault, Central Andes of Ecuador. Frontiers in Earth Science, 8, 193.

Baize, S., Nurminen, F., Sarmiento, A., Dawson, T., Takao, M., Scotti, O., ... \& Civico, R. (2020b). A worldwide and Unified Database of Surface Ruptures (SURE) for fault displacement hazard analyses. Seismological Research Letters, 91(1), 499-520.

Ballantyne, C. K. (2002). Paraglacial geomorphology. Quaternary Science Reviews, 21(18-19), 1935-2017. 
Barberi, F., Coltelli, M., Ferrara, G., Innocenti, F., Navarro, J. M., \& Santacroce, R. (1988). Plio-quaternary volcanism in Ecuador. Geological Magazine, 125(1), 1-14.

Beauval, C., Yepes, H., Bakun, W. H., Egred, J., Alvarado, A., \& Singaucho, J. C. (2010). Locations and magnitudes of historical earthquakes in the Sierra of Ecuador (1587-1996). Geophysical Journal International, 181(3), 16131633.

Beauval, C., Yepes, H., Palacios, P., Segovia, M., Alvarado, A., Font, Y., ... \& Vaca, S. (2013). An earthquake catalog for seismic hazard assessment in Ecuador. Bulletin of the Seismological Society of America, 103(2A), 773-786.

Béguelin, P., Chiaradia, M., Beate, B., \& Spikings, R. (2015). The Yanaurcu volcano (Western Cordillera, Ecuador): A field, petrographic, geochemical, isotopic and geochronological study. Lithos, 218-219, 37-53. Bernard, B., Robin, C., Beate, B., Hidalgo. S. (2011) Nuevo modelo evolutivo y actividad eruptive reciente del volcán Chachimbiro. Extended abstract in the "7mas Jornadas en Ciencias de la Tierra", Escuela Politécnica Nacional, November 23-25, Quito (Ecuador), pp 119-122

Bernard, B., Hidalgo, S., Robin, C., Beate, B., \& Quijozaca, J. (2014). The 3640-3510 BC rhyodacite eruption of Chachimbiro compound volcano, Ecuador: a violent directed blast produced by a satellite dome. Bulletin of Volcanology, 76(9), 849.

Bellver-Baca, M. T., Chiaradia, M., Beate, B., Beguelin, P., Deriaz, B., Mendez-Chazarra, N., \& Villagómez, D. (2020). Geochemical evolution of the Quaternary Chachimbiro Volcanic Complex (frontal volcanic arc of Ecuador). Lithos, 356, 105237.

Bès De Berc, S., Soula, J. C., Baby, P., Souris, M., Christophoul, F., \& Rosero, J. (2005). Geomorphic evidence of active deformation and uplift in a modern continental wedge-top-foredeep transition: example of the eastern Ecuadorian Andes. Tectonophysics, 399(1-4), 351-380.

Blackwelder, E. (1928). The recognition of fault scarps. The Journal of Geology, 36(4), 289-311. Boland, M.P., Pilatasig, L.F., Ibadango, C.E., McCourt, W.J., Aspden, J.A., Hughes, R.A.; Beate, B., (1998) Mapa geologico de la cordillera occidental del Ecuador entre $0^{\circ}-1^{\circ} \mathrm{N}$. Escala 1:200.000

Bronk Ramsey, C., 2009. Bayesian Analysis of Radiocarbon Dates. Radiocarbon. doi:10.1017/S0033822200033865 Bucknam, R. C., and Anderson, R. E. (1979). Estimation of fault scarp ages from a scarp-height-slope-angle relationship. Geology 7,11-14.

Champenois, J., Baize, S., Vallée, M., Jomard, H., Alvarado, A., Espin, P., et al. (2017). Evidence of Surface Rupture Associated With a Low-Magnitude ( M w 5.0) Shallow Earthquake in the Ecuadorian Andes. J. Geophys. Res. Solid Earth. doi:10.1002/2017JB013928 
Chen, Y. G., Lai, K. Y., Lee, Y. H., Suppe, J., Chen, W. S., Lin, Y. N. N., ... \& Kuo, Y. T. (2007). Coseismic fold scarps and their kinematic behavior in the 1999 Chi-Chi earthquake Taiwan. Journal of Geophysical Research: Solid Earth, 112(B3).

Chiaradia, M., Müntener, O., \& Beate, B. (2011). Enriched basaltic andesites from mid-crustal fractional crystallization, recharge, and assimilation (Pilavo Volcano, Western Cordillera of Ecuador). Journal of Petrology, 52(6), 1107-1141.

Cinti, F. R., De Martini, P. M., Pantosti, D., Baize, S., Smedile, A., Villani, F., ... \& Pizzimenti, L. (2019). 22-kyrLong Record of Surface Faulting Along the Source of the 30 October 2016 Earthquake (Central Apennines, Italy), From Integrated Paleoseismic Data Sets. Journal of Geophysical Research: Solid Earth, 124(8), 9021-9048.

Clapperton, C. M., \& Vera, R. (1986). The Quaternary glacial sequence in Ecuador: a reinterpretation of the work of Walter Sauer. Journal of Quaternary Science, 1(1), 45-56.

Clapperton, C.M., Hall, M., Mothes, P., Hole, M.J., Still, J.W., Helmens, K.F., Kuhry, P., Gemmell, A.M.D., (1997). A Younger Dryas icecap in the equatorial Andes. Quaternary Research 47, 13-28.

Colmet-Daage, F., Cucalon, F., Delaune, M., Gautheyrou, J., Gautheyrou, M., \& Moreau, B. (1967). Caractéristiques de quelques sols d'Equateur dérivés de cendres volcaniques: 1ère partie. Essai de caractérisation des sols des régions tropicales humides. Cahiers ORSTOM. Série Pédologie, 5(1), 3-38 Coltorti, M., \& Ollier, C. D. (1999). The significance of high planation surface in the Andes of Ecuador. Geological Society, London, Special Publications, 162(1), 239-253.

Coltorti, M., \& Ollier, C. D. (2000). Geomorphic and tectonic evolution of the Ecuadorian Andes. Geomorphology, 32(1-2), 1-19.

Córdova-Regalado, A. E. (2013). Estudio de micro-sismicidad para los proyectos geotérmicos: Chacana y Chachimbiro (Bachelor's thesis, Quito, 2013.)

Costa, C., Alvarado, A., Audemard, F., Audin, L., Benavente, C., Bezerra, F. H., ... \& Santibañez, I. (2020). Hazardous faults of South America; compilation and overview. Journal of South American Earth Sciences, 104, 102837.

Dávila F., (1990), Geodinámica Plio-Cuaternaria de la Cuenca de Latacunga-Ambato, Callejón Interandino: sector entre Salcedo y Píllaro, Eng. These, Escuela Politécnica Nacional Quito, 176p.

Deniaud Y., (2000), Enregistrements sédimentaire et structural de l'évolution géodynamique des Andes Equatoriennes au cours du Néogène: étude des bassins d'avant-arc et bilans de masse, Géologie Alpine, Mémoire H.S No. 32 Université Joseph Fourier Grenoble, pp. 157.

De Novellis, V., Atzori, S., De Luca, C., Manzo, M., Valerio, E., Bonano, M., ... \& Casu, F. (2019). DInSAR analysis and analytical modeling of Mount Etna displacements: The December 2018 volcano-tectonic crisis. Geophysical Research Letters, 46(11), 5817-5827. 
1017

1018

1019

1020

1021

1022

1023

1024

1025

1026

1027

1028

1029

1030

1031

1032

1033

1034

1035

1036

1037

1038

1039

1040

1041

1042

1043

1044

1045

1046

1047

1048

1049

Dumont, S., Socquet, A., Grandin, R., Doubre, C., \& Klinger, Y. (2016). Surface displacements on faults triggered by slow magma transfers between dyke injections in the 2005-2010 rifting episode at Dabbahu-Manda-Hararo rift (Afar, Ethiopia). Geophysical Journal International, 204(1), 399-417.

DuRoss, C. B., Gold, R. D., Briggs, R. W., Delano, J. E., Ostenaa, D. A., Zellman, M. S., ... \& Mahan, S. A. (2020). Holocene earthquake history and slip rate of the southern Teton fault, Wyoming, USA. Bulletin, 132(7-8), 15661586.

Ebmeier, S. K., Elliott, J. R., Nocquet, J. M., Biggs, J., Mothes, P., Jarrín, P., ... \& Samsonov, S. V. (2016). Shallow earthquake inhibits unrest near Chiles-Cerro Negro volcanoes, Ecuador-Colombian border. Earth and Planetary Science Letters, 450, 283-291.

Ego, F., (1995) Accommodation de la convergence oblique dans une chaine de type cordilleraine: les Andes de Equateur. Mémoire PhD, Université de Paris-Sud Centre d’Orsay, pp. 209.

Ego, F., Sébrier, M., Carey-Gailhardis, E., \& Beate, B. (1996a). Do the Billecocha normal faults (Ecuador) reveal extension due to lithospheric body forces in the northern Andes?. Tectonophysics, 265(3-4), 255-273.

Ego, F., Sébrier, M., Lavenu, A., Yepes, H., \& Egues, A. (1996b). Quaternary state of stress in the Northern Andes and the restraining bend model for the Ecuadorian Andes. Tectonophysics, 259(1-3), 101-116.

Egred, J., 2009.Terremotos del Ecuador, dos volumen, Escuela Politecnica Nacional, Instituto Geofísico, Internal Report.

Egüez, A., 1986. Evolution Cénozoïque de la Cordillère Occidentale Septentrionale d`Equateur: Les minéralisation associées. Unpublished PhD thesis; Université Pierre et Marie Curie, Paris. 116p Egüez, A., Alvarado, A., Yepes, H., Machette, M. N., Costa, C., Dart, R. L., \& Bradley, L. A. (2003). Database and map of Quaternary faults and folds of Ecuador and its offshore regions. US Geological Survey Open-File Report, $3,289$.

Fiorini, E., \& Tibaldi, A. (2012). Quaternary tectonics in the central Interandean Valley, Ecuador: Faultpropagation folds, transfer faults and the Cotopaxi Volcano. Global and Planetary Change, 90, 87-103.

Galland, O., Hallot, E., Cobbold, P. R., Ruffet, G., \& de Bremond D'Ars, J. (2007). Volcanism in a compressional Andean setting: A structural and geochronological study of Tromen volcano (Neuquén province, Argentina). Tectonics, 26(4).

García-Villarruel, A. P. (2018). Origen de los enjambres sísmicos en Imantag, provincia de Imbabura: eneromayo 2016 (Bachelor's thesis, Quito: UCE).

Gunkel, G., Beulker, C., Grupe, B., \& Viteri, F. (2009). Survey and assessment of post volcanic activities of a young caldera lake, Lake Cuicocha, Ecuador. Natural Hazards and Earth System Sciences, 9(3), 699.

Gutscher, M. A., Malavieille, J., Lallemand, S., \& Collot, J. Y. (1999). Tectonic segmentation of the North Andean margin: impact of the Carnegie Ridge collision. Earth and Planetary Science Letters, 168(3-4), 255-270. 
Gutiérrez, F., Ortuño, M., Lucha, P., Guerrero, J., Acosta, E., Coratza, P., ... \& Soldati, M. (2008). Late Quaternary episodic displacement on a sackung scarp in the central Spanish Pyrenees. Secondary paleoseismic evidence?. Geodinamica Acta, 21(4), 187-202.

Hall, M.L., Beate, B., 1991. El Volcanism o Plio-Cuaternario en los Andes del Ecuador. In: El Paisaje Volcánico de la Sierra Ecuatoriana. Corp. Edit. Nac., Quito, pp. 5-18.

Hall, M. L., Samaniego, P., Le Pennec, J. L., \& Johnson, J. B. (2008). Ecuadorian Andes volcanism: A review of Late Pliocene to present activity. Journal of Volcanology and Geothermal Research, 176(1), 1-6.

Hampel, A., \& Hetzel, R. (2006). Response of normal faults to glacial-interglacial fluctuations of ice and water masses on Earth's surface. Journal of Geophysical Research: Solid Earth, 111(B6).

Hampel, A. (2017). Response of faults to climate-induced changes of ice sheets, glaciers and lakes. Geology Today, 33(1), 12-18.

Hippolyte, J. C., Brocard, G., Tardy, M., Nicoud, G., Bourlès, D., Braucher, R., ... \& Souffaché, B. (2006). The recent fault scarps of the Western Alps (France): Tectonic surface ruptures or gravitational sackung scarps? A combined mapping, geomorphic, levelling, and 10Be dating approach. Tectonophysics, 418(3-4), 255-276.

Hogg, A. G., Heaton, T. J., Hua, Q., Palmer, J. G., Turney, C. S., Southon, J., ... \& Pearson, C. (2020). SHCal20 Southern Hemisphere calibration, 0-55,000 years cal BP. Radiocarbon, 62(4), 759-778.

Hughes, R. A., \& Pilatasig, L. F. (2002). Cretaceous and Tertiary terrane accretion in the Cordillera Occidental of the Andes of Ecuador. Tectonophysics, 345(1-4), 29-48.

Hungerbühler, D., Steinmann, M., Winkler, W., Seward, D., Egüez, A., Peterson, D. E., ... \& Hammer, C. (2002). Neogene stratigraphy and Andean geodynamics of southern Ecuador. Earth-Science Reviews, 57(1-2), 75-124. Instituto Geofísico - Escuela Politécnica Nacional, Earthquake catalog, last access November 2020. Jaillard, E., Lapierre, H., Ordoñez, M., Álava, J.T., Amórtegui, A., Vanmelle, J. (2009). Accreted oceanic terranes in Ecuador: southern edge of the Caribbean Plate? Geol. Soc. Lond. Spec. Publ. doi:10.1144/SP328.19 Jarman, D. (2006). Large rock slope failures in the Highlands of Scotland: characterisation, causes and spatial distribution. Engineering Geology, 83(1-3), 161-182.

Jarman, D., Calvet, M., Corominas, J., Delmas, M., \& Gunnell, Y. (2014). Large-scale rock slope failures in the eastern pyrenees: Identifying a sparse but significant population in paraglacial and parafluvial contexts. Geografiska Annaler: Series A, Physical Geography, 96(3), 357-391.

Jomard, H., Lebourg, T., \& Guglielmi, Y. (2014). Morphological analysis of deep-seated gravitational slope deformation (DSGSD) in the western part of the Argentera massif. A morpho-tectonic control? Landslides, $11(1), 107-117$. 
1081

1082

1083

1084

1085

1086

1087

1088

1089

1090

1091

1092

1093

1094

1095

1096

1097

1098

1099

1100

1101

1102

1103

1104

1105

1106

1107

1108

1109

1110

1111

1112

1113

Kellogg, J. N., Vega, V., Stallings, T. C., \& Aiken, C. L. (1995). Tectonic development of Panama, Costa Rica, and the Colombian Andes: constraints from global positioning system geodetic studies and gravity. Special PapersGeological Society of America, 75-75.

Lavenu, A., Winter, T., Dávila, F., 1995. A Pliocene-Quaternary compressional basin in the Interandean Depression, Central Ecuador. Geophys. J. Int. doi:10.1111/j.1365-246X.1995.tb03527.x

Lebras, M., Megard, F., Dupuy, C., \& Dostal, J. (1987). Geochemistry and tectonic setting of pre-collision Cretaceous and Paleogene volcanic rocks of Ecuador. Geological Society of America Bulletin, 99(4), 569-578.* Legrand, D., Calahorrano, A., Guillier, B., Rivera, L., Ruiz, M., Villagómez, D., \& Yepes, H. (2002). Stress tensor analysis of the 1998-1999 tectonic swarm of northern Quito related to the volcanic swarm of Guagua Pichincha volcano, Ecuador. Tectonophysics, 344(1-2), 15-36.

Leonard, M. (2010). Earthquake fault scaling: Self-consistent relating of rupture length, width, average displacement, and moment release. Bulletin of the Seismological Society of America, 100(5A), 1971-1988.

Litherland, M., \& Aspden, J. A. (1992). Terrane-boundary reactivation: a control on the evolution of the Northern Andes. Journal of South American Earth Sciences, 5(1), 71-76.

MacQueen, P., Delgado, F., Reath, K., Pritchard, M. E., Bagnardi, M., Milillo, P., ... \& Miranda, R. (2020). Volcano-Tectonic Interactions at Sabancaya Volcano, Peru: Eruptions, Magmatic Inflation, Moderate Earthquakes, and Fault Creep. Journal of Geophysical Research: Solid Earth, 125(5), e2019J B019281.

Marinière, J., Nocquet, J. M., Beauval, C., Champenois, J., Audin, L., Alvarado, A., ... \& Socquet, A. (2020). Geodetic evidence for shallow creep along the Quito fault, Ecuador. Geophysical Journal International, 220(3), 2039-2055.

Marsh, E. J., Bruno, M. C., Fritz, S. C., Baker, P., Capriles, J. M., \& Hastorf, C. A. (2018). IntCal, SHCal, or a mixed curve? Choosing a $14 \mathrm{C}$ calibration curve for archaeological and paleoenvironmental records from tropical South America. Radiocarbon, 60(3), 925.

Mattila, J., Ojala, A. E. K., Ruskeeniemi, T., Palmu, J. P., Aaltonen, I., Käpyaho, A., ... \& Sutinen, R. (2019). Evidence of multiple slip events on postglacial faults in northern Fennoscandia. Quaternary Science Reviews, 215, 242252.

McCalpin, J. P. (1999). Criteria for determining the seismic significance of sackungen and other scarplike landforms in mountainous regions. Techniques for Identifying Faults and Determining their Origins. US Nuclear Regulatory Commission, Washington, 2-55.

McCalpin, J. P. (Ed.). (2009). Paleoseismology. Academic press. 629pp. ISBN:9780123735768

McCalpin, J. P., Gutierrez, F., Bruhn, R. L., Guerrero, J., Pavlis, T. L., \& Lucha, P. (2020). Tectonic geomorphology and late Quaternary deformation on the Ragged Mountain fault, Yakutat microplate, south coastal Alaska. Geomorphology, 351, 106875. 
Mothes, P. and Hall, M. L.: El paisaje interandino y su formacion' por eventos volcanicos de gran magnitude, Estudios de Geografia, 4, 19-38, 1991

Navarrete, W. F., Le Pennec, J. L., Solano, S., Liorzou, C., \& Ruiz, G. A. (2020). A first reconstruction of the evolution of Cubilche Volcanic Complex, Imbabura Province, Ecuador. Journal of Volcanology and Geothermal Research, 406, 107023.

Nocquet, J.-M., Villegas-Lanza, J.C., Chlieh, M., Mothes, P.A., Rolandone, F., Jarrin, P., et al. (2014). Motion of continental slivers and creeping subduction in the northern Andes. Nat. Geosci. doi:10.1038/ngeo2099 Ortuño, M. (2013). Criterios para distinguir fallas neotectónicas de otras fallas activas: Ejemplos de los Pirineos Centrales. Cuaternario y geomorfología: Revista de la Sociedad Española de Geomorfología y Asociación Española para el Estudio del Cuaternario, 27(3), 73-82.

Pánek, T., \& Klimeš, J. (2016). Temporal behavior of deep-seated gravitational slope deformations: A review. Earth-Science Reviews, 156, 14-38.

Pindell, J.L., Kennan, L. (2009). Tectonic evolution of the Gulf of Mexico, Caribbean and northern South America in the mantle reference frame: an update. Geol. Soc. Lond. Spec. Publ. doi:10.1144/SP328.1 Rhoades, R. (2008). Disappearance of the glacier on Mama Cotacachi: ethnoecological research and climate change in the Ecuadorian Andes. Pirineos, 163, 37-50.

Rodbell, D. T., Smith, J. A., \& Mark, B. G. (2009). Glaciation in the Andes during the Lateglacial and Holocene. Quaternary Science Reviews, 28(21-22), 2165-2212.

Saqui, D. C. (2019). Análisis Cinemático del Sistema de Fallas de Billecocha, utilizando evidencia Geomorfológica y Geofísica, Cantón Cotacachi, Provincia de Imbabura (Bachelor's thesis, Quito, 2019.)

Sierra, D., Hidalgo, S., Almeida, M., Vigide, N., Lamberti, M. C., Proaño, A., \& Narváez, D. F. (2020). Temporal and spatial variations of $\mathrm{CO} 2$ diffuse volcanic degassing on Cuicocha Caldera Lake - Ecuador. Journal of Volcanology and Geothermal Research, 107145.

Singaucho, J. C. (2009). Mapa de máximas intensidades sísmicas del Ecuador criterios estructurales para mejorar la estimación de intensidades (Bachelor's thesis, QUITO/EPN/2009).

Soulas J.P., (1988). Tectónica Activa y Riesgo Sísmico, Proyecto UNDRO-EPN, informe técnico inédito, pp 10. Soulas J.P., Yepes H., Egüez A., (1987). Guía de salida al campo del Curso de Neotéctonica para fines de Riesgo Sísmico, inédito, $13 \mathrm{pp}$.

Spikings, R. A., Winkler, W., Seward, D., \& Handler, R. (2001). Along-strike variations in the thermal and tectonic response of the continental Ecuadorian Andes to the collision with heterogeneous oceanic crust. Earth and Planetary Science Letters, 186(1), 57-73. 
Steinmann, M., Hungerbühler, D., Seward, D., \& Winkler, W. (1999). Neogene tectonic evolution and exhumation of the southern Ecuadorian Andes: a combined stratigraphy and fission-track approach. Tectonophysics, 307(3-4), 255-276.

Strunk, A., Olsen, J., Sanei, H., Rudra, A., \& Larsen, N. K. (2020). Improving the reliability of bulk sediment radiocarbon dating. Quaternary Science Reviews, 242, 106442.

Tebano, C., Pasanisi, F., \& Grauso, S. (2017). QMorphoStream: processing tools in QGIS environment for the quantitative geomorphic analysis of watersheds and river networks. Earth Science Informatics, 10(2), 257-268. Tibaldi, A., Rovida, A., Corazzato, C. (2007). Late Quaternary kinematics, slip-rate and segmentation of a major Cordillera-parallel transcurrent fault: The Cayambe-Afiladores-Sibundoy system, NW South America. J. Struct. Geol. doi:10.1016/j.jsg.2006.11.008

Tibaldi, A. (2008). Contractional tectonics and magma paths in volcanoes. Journal of Volcanology and Geothermal Research, 176(2), 291-301.

Tibaldi, A., Pasquarè, F., \& Tormey, D. (2009). Volcanism in reverse and strike-slip fault settings. In New frontiers in integrated solid earth sciences (pp. 315-348). Springer, Dordrecht.

Ustaszewski, M. E., Hampel, A. \& Pfiffner, O. A. (2008). Composite faults in the Swiss Alps formed by the interplay of tectonics, gravitation and postglacial rebound: an integrated field and modelling study. Swiss Journal of Geosciences, 101(1), 223-235.

Vaca, S., Vallée, M., Nocquet, J. M., \& Alvarado, A. (2019). Active deformation in Ecuador enlightened by a new waveform-based catalog of earthquake focal mechanisms. Journal of South American Earth Sciences, 93, 449461.

Vallejo, C., Winkler, W., Spikings, R. A., Luzieux, L., Heller, F., \& Bussy, F. (2009). Mode and timing ofterrane accretion in theforearc of the Andes in Ecuador. Backbone of the Americas: shallow subduction, plateau uplift, and ridge and terrane collision, 204, 197.

Villamor, P., Berryman, K. R., Nairn, I. A., Wilson, K., Litchfield, N., \& Ries, W. (2011). Associations between volcanic eruptions from Okataina volcanic center and surface rupture of nearby active faults, Taupo rift, New Zealand: Insights into the nature of volcano-tectonic interactions. Bulletin, 123(7-8), 1383-1405.

White, S. M., Trenkamp, R., \& Kellogg, J. N. (2003). Recent crustal deformation and the earthquake cycle along the Ecuador-Colombia subduction zone. Earth and Planetary Science Letters, 216(3), 231-242.

Winter, T., Avouac, J.-P., Lavenu, A. (1993). Late Quaternary kinematics of the Pallatanga strike-slip fault (Central Ecuador) from topographic measurements of displaced morphological features. Geophys. J. Int. doi:10.1111/j.1365-246X.1993.tb01500.x

Yeats, R. S. (1986). Active faults related to folding. Active tectonics, 63-79. 
1177 Yepes, H., Audin, L., Alvarado, A., Beauval, C., Aguilar, J., Font, Y., \& Cotton, F. (2016). A new view for the

1178 geodynamics of Ecuador: Implication in seismogenic source definition and seismic hazard assessment.

1179 Tectonics, 35(5), 1249-1279.

1180 Ypiales, F.F.G. (2019). El terremoto de Cotacachi de 1955, relocalización de la fuente sismogénica utilizando

1181 EMS-98 (Bachelor's thesis, Quito: UCE).

1182 Zehetner, F., Miller, W. P., \& West, L. T. (2003). Pedogenesis of volcanic ash soils in Andean Ecuador. Soil

1183 Science Society of America Journal, 67(6), 1797-1809.

\section{Supplementary material}

1185 Zip file containing data, please read the readme.txt file 